\title{
BMJ Open Working towards a comprehensive understanding of HPV and cervical cancer among Indigenous women: a qualitative systematic review
}

\author{
Sneha Sethi (D) , ${ }^{1}$ Brianna Poirier, ${ }^{1}$ Karen Canfell, ${ }^{2}$ Megan Smith, ${ }^{2}$ Gail Garvey (D) , ${ }^{3}$ \\ Joanne Hedges, ${ }^{1}$ Xiangqun Ju (D) , ${ }^{1}$ Lisa M Jamieson (D) ${ }^{1}$
}

To cite: Sethi S, Poirier B, Canfell $\mathrm{K}$, et al. Working towards a comprehensive understanding of HPV and cervical cancer among Indigenous women: a qualitative systematic review. BMJ Open 2021;11:e050113. doi:10.1136/ bmjopen-2021-050113

- Prepublication history and additional supplemental material for this paper are available online. To view these files, please visit the journal online (http://dx.doi.org/10.1136/ bmjopen-2021-050113).

Received 13 February 2021 Accepted 08 June 2021

Check for updates

(c) Author(s) (or their employer(s)) 2021. Re-use permitted under CC BY-NC. No commercial re-use. See rights and permissions. Published by BMJ.

${ }^{1}$ Australian Research Centre for Population Oral Health, Faculty of Health Sciences, The University of Adelaide, Adelaide, South Australia, Australia ${ }^{2}$ Cancer Research Division, Cancer Council New South Wales, Woolloomooloo, New South Wales, Australia ${ }^{3}$ Wellbeing and Preventable Chronic Diseases Division, Menzies School of Health Research Brisbane Office, Brisbane, Queensland, Australia

Correspondence to

Dr Sneha Sethi;

sneha.sethi@adelaide.edu.au

\section{ABSTRACT}

Rationale Indigenous peoples carry a disproportionate burden of infectious diseases and cancers and are overrepresented among the socially disadvantaged of most countries. Human papillomavirus (HPV) is a risk factor and causative agent of cervical, oropharyngeal and other cancers. Recent literature shows evidence of Indigenous populations being at increased risk of HPV infections and its associated cancers.

Objective This is a qualitative systematic review. The objective of this study was to explore the experiences and barriers Indigenous women face in relation to HPV awareness, knowledge and cervical screening, in order to better understand factors that may mitigate against or facilitate prevention efforts for HPV infection and associated cancers.

Methods Two investigators independently searched MEDLINE, PubMed, SCOPUS and Web of Science databases (for articles published from inception until 30 June 2020) using a prespecified search strategy to identify qualitative studies on narratives of Indigenous women regarding HPV infection awareness, knowledge and cervical screening, across all geographic and income-level settings. Using a 'meta-study' approach, a social ecological model of cervical screening, infection and associated cancer prevention among Indigenous populations was formulated.

Results Five core themes were identified and formulated within the social ecological model; intrapersonal factors, interpersonal factors, institutional/organisational factors, sociocultural/community factors and public policy. These collectively formed the proposed social ecological model of HPV infection awareness and cervical cancer prevention among Indigenous women. This model has been synthesised by taking into account personal stories of Indigenous women and healthcare workers, thus offering a more nuanced, organised, structured and culturally sensitive approach to policy translation.

Conclusion The social ecological model of HPV infection awareness and cervical cancer prevention among Indigenous women offers a holistic and practical approach for Indigenous health policy makers. It clearly addresses the high risk of Indigenous populations at a global level in experience of both HPV infection and HPV-related cancers. PROSPERO registration number CRD42020207643.
Strengths and limitations of this study

- This systematic review is the first to address the qualitative aspects of human papillomavirus (HPV) infection and associated cancers among Indigenous women at a global level. The review adhered to all protocols to ensure transparency and legitimacy.

- Another strength is the summary of communityprovided solutions, in the form of personal narratives, to help decrease transmission of HPV infection and to, in turn, prevent HPV-related cancers.

- Our study highlights the continuing impact of trauma at the public policy level, with our findings providing important evidence of the work required to address the resulting disparities across all health indicators that have resulted from this trauma.

- Limitations include the decision to not include male participants, as the current statistics show a dramatic increase in the incidence of HPV associated oropharyngeal carcinoma among men.

- The community-identified solutions presented are mainly from one study; this demonstrates the need for community feedback to be embedded within Indigenous health research projects so that future policies can be derived from community suggestions that will have greater resonance and likely acceptance.

\section{INTRODUCTION}

Indigenous peoples, as defined by the United Nations (2004), includes all "people with a historical continuity with pre-invasion and pre-colonial societies that developed on their territories, and who consider themselves distinct from other sectors of the societies now prevailing on those territories'. Globally, Indigenous peoples experience disproportionate health inequalities, in comparison to non-Indigenous populations, due to a unique history of colonial settlement. This has resulted in environmental dispossession of traditional lands and resources, which has negatively impacted spiritual connections 
with the land and with each other. ${ }^{1-4}$ Indigenous peoples are over-represented among the socially disadvantaged in almost every country, particularly in developed countries. ${ }^{5}$ Public policy created by colonial settlers in many countries has been aimed at the assimilation and cultural annihilation of Indigenous peoples, resulting in mass loss of culture, language and community. Examples of assimilation policies include the Residential School System in Canada, ${ }^{6}$ the Stolen Generations of Australia ${ }^{7}$ and racial amalgamation in New Zealand. ${ }^{8}$ Adelson's $(2005)^{9}$ notion of 'the embodiment of inequity', and similar works ${ }^{10} 11$ have demanded attention be paid to the ways in which the impacts of colonial legacies, marginalisation and discrimination manifest in Indigenous peoples' health outcomes. ${ }^{11}$ Previous works ${ }^{12}{ }^{13}$ have explored the relationship between colonisation and the intersectional nature of social determinants of health, such as race, demonstrating that healthcare patterns are rooted in historic economic, social and political circumstances and power relations. ${ }^{12}$ This literature provides insight into the commonality of high-risk health profiles experienced by Indigenous peoples around the world and has created awareness of the need to take special measures to protect the rights of Indigenous peoples. ${ }^{14} 15$

Human papillomavirus (HPV) infection and associated cancers have gained significant public and research attention in recent decades. WHO has launched a three step programme for elimination of cervical cancer by $2050,{ }^{16}$ and the International Society for Papillomavirus Research has demonstrated support ${ }^{17}$ for the programme with a call for equity in elimination strategies, particularly reinforcing best practices for Indigenous populations. While screening tools, such as the Papanicolaou test (Pap test), have been successful in reducing cervical cancer overall, and HPV vaccination programmes are expected to reduce rates of HPV infection and all HPV-related cancers, Indigenous communities continue to experience significantly higher rates of cervical cancer and oncogenic HPV infection compared with non-Indigenous populations. ${ }^{18-22}$ This discrepancy in cancer is related to Indigenous women being less likely to have been screened ${ }^{23-25}$ and compounded by implications of colonial legacies. ${ }^{1-4}$

It has been reported ${ }^{26}$ that the prevalence of high-risk HPV infection related to invasive cervical cancer was $32.7 \%$ in American Indian/Alaskan Native populations in the USA compared with $24.9 \%$ in the non-Indigenous populations. A crude incidence of HPV related cervical cancer in nine Indigenous populations of the Brazilian Amazon was 46/100 000; which indicated a public health concern, also suggesting a weakness in the current secondary prevention programme. ${ }^{27}$ Additionally, a study of three specific tribes (Aymara, Mestizo, Quechua) of Bolivian Andean women has revealed an unexpected number of cases infected with HPV. ${ }^{28}$ The number of sexual partners was an important predictor of HPV infection in the Metit population of Canada. ${ }^{29}$ The younger age of onset of sexual practices and less likely use of condoms has been observed in Maori tribes also. ${ }^{30} \mathrm{~A}$ Pilaga community in
Northern Argentina showed very high prevalence of HPV infection $(46.7 \%) .{ }^{31}$ Several reasons for not attending cervical cancer screening were described by Canadian Inuit women, including previous painful experiences and embarrassment to be examined by a male nurse. ${ }^{29}$

HPV-related cancers are mediated by risk factors such as sexual behaviour, tobacco use and screening participation, but these relevant health behaviours of affected Indigenous Peoples coexist within multidimensional contexts. ${ }^{32}{ }^{33}$ Bronfenbrenner's social ecological model provides a theoretical framework in which to understand the micro and macro dimensions of a phenomenon, by simultaneously considering related political, social, physical and economic environments. ${ }^{34} 35$ Many health promotion efforts focus on individual choice, ignoring the social context of health-related behaviours. The social ecological model acknowledges the importance of the social environmental impacts on human health, beyond the ideology of individual responsibility. ${ }^{35}$ It may be that current HPV prevention programmes are not successfully recognising and/or incorporating strategies targeted at factors beyond the individual. This is a particular shortcoming among initiatives targeting Indigenous communities who, at a global level, are much more collectivistic and group-oriented than their non-Indigenous peers. ${ }^{18}$

This review therefore seeks to better understand facilitators and barriers to HPV and associated cancer prevention, as experienced by Indigenous peoples on an international scale at each level of the social ecological model. ${ }^{35}$ Combining existing literature within the framework of the model acknowledges the significance of Indigenous culture and its interaction with socioeconomic conditions. ${ }^{18} 35$ The objective of this systematic review was to synthesise qualitative perspectives and experiences of Indigenous women and healthcare workers in the context of HPV infection, associated cervical cancer and screening methods to establish a foundation that might better facilitate targeted, holistic and culturally relevant prevention strategies.

\section{MATERIALS AND METHODS}

This systematic review has been registered in PROSPERO and the Joanna Briggs Systematic Reviews register. A prior search of the PROSPERO register revealed no similar studies. Both the Preferred Reporting Items for Systematic Reviews and Meta-Analyses guidelines ${ }^{36}$ and the Enhancing Transparency in Reporting the Synthesis of Qualitative Research statement (table 1) were followed in the conduct of this systematic review.

\section{Patient and public involvement}

No patient or public involvement was undertaken in this study.

\section{Positionality}

Acknowledging that personal experiences and beliefs heavily influence research perspectives, it is critical for 
Table 1 Enhancing Transparency in Reporting the Synthesis of Qualitative Research checklist

\begin{tabular}{lll} 
Item & Description & Reported on page \\
\hline Aim & $\begin{array}{l}\text { Awareness of and barriers to HPV infection screening among Indigenous } \\
\text { women globally }\end{array}$ & 2 \\
Synthesis methodology & $\begin{array}{l}\text { Thematic content analysis guided initial data extraction for synthesis, and } \\
\text { the social ecological model provided a theoretical framework to understand } \\
\text { synthesised finding }\end{array}$ & $4-5$
\end{tabular}

$\begin{array}{ll}\text { Approach to searching } & \begin{array}{l}\text { Pre-established search strategy which involved using terms describing the } \\ \text { population of interest, the phenomenon we are researching as well as study } \\ \text { designs to be included }\end{array}\end{array}$

Inclusion criteria Inclusion: studies from inception till June 2020 were included in the study.

Research based on the experiences of women of Indigenous identity or healthcare worker of Indigenous identity, personal illustrations of HPV knowledge and cervical cancer, first-person accounts; topics focused on cancers associated with HPV infection; qualitative and/or narrative, or mixed methodology; available in English; accessible via hardcopy or download; peerreviewed

Exclusion: research-based only on vaccination for HPV; non-Indigenous participants; only Indigenous male narratives; quantitative methodology

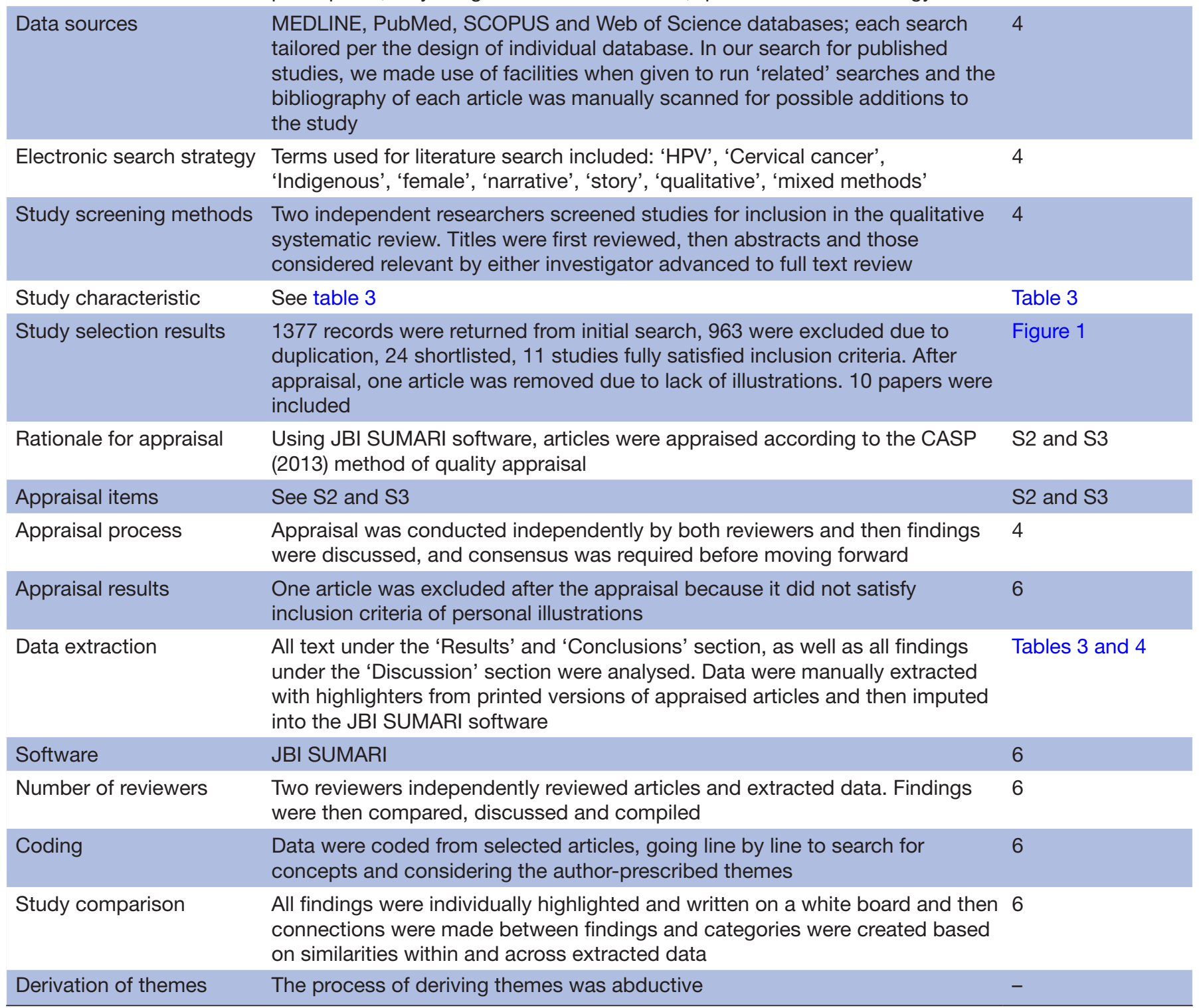


Table 1 Continued

\begin{tabular}{|c|c|c|}
\hline Item & Description & $\begin{array}{l}\text { Reported on page } \\
\#\end{array}$ \\
\hline Quotations & Table 2 & $6-18$, table 4 \\
\hline Synthesis output & Discussion and figure 2 & $\begin{array}{l}\text { 19-20, } \\
\text { table } 4 \text {,figure } 2\end{array}$ \\
\hline
\end{tabular}

HPV, human papillomavirus; JBI, Joanna Briggs Institute; SUMARI, System for the Unified Management, Assessment and Review of Information.

researchers to self-situate. This review is a result of the desire to prioritise individual voices and stories of Indigenous women. After hearing first-hand accounts of various health disparities experienced by Indigenous women in South Australia, while conducting field work for a different HPV project, the primary reviewers (SS and $\mathrm{BP})$ discussed the importance of the person behind a statistic and the desire to synthesise existing knowledge in HPV literature was established in order to identify future research steps. While both non-Indigenous researchers, SS is an oral pathologist with experience working with Indigenous populations in Australia and BP has qualitative experience with community-engaged scholarship in the context of Indigenous health in Canada and Australia. The supporting research team consists of Indigenous and non-Indigenous scholars with vast experience in the realm of Indigenous health research.

\section{Identifying studies for inclusion}

The reviewers used a pre-established search strategy, ${ }^{37}$ which involved using terms (and their edited variants) describing the population of interest, the phenomenon being researched, as well as the included study designs (online supplemental file 1). Two investigators (SS and BP) independently screened the literature for eligible articles using MEDLINE, PubMed, SCOPUS and Web of Science databases from inception until June 2020. For example, the search strategy used for PubMed Database was as follows: First Nation/First Nations/Pacific Islander/Pacific Islanders/Torres Strait Islander/Torres Strait* Islanders/Aborigin*/Alaska*/Aleut*/Amerind*/ American Indian/Arctic/Aymara/ Bushmen/Chukchi/ Chukotka*/Circumpolar/Eskimo*/Greenland*/ Hmong/Indian*/Indigen*/Inuit*/Inupiaq/Inupiat/ Khanty/Maori*/Mapuche/Metis/Native*/Navaho*/ Navajo*/Nenets/Quechua/Saami/Sami/Samoan*/ Siberia*/Skolt/Tribal/Tribe*/Xingu*/Yup'ik/Yupik/ Zuni/"African continental ancestry group"/"African continental ancestry group"/"Asian continental ancestry group"/"Health Services, Indigenous"/"Oceanic ancestry group"/"arctic regions"/"ethnic groups", "HPV", "Human Papillomavirus", "Papillomavirus", "HPV 18", "HPV*", "Qualitative", "awareness", "barriers", "screening". The search was tailored as per the design of individual databases.

In the search for published studies, the reviewers made use of facilities where the option was given to run 'related' searches, where similar studies are automatically identified. The bibliography of each article was scanned manually for possible additions to the search. The titles and abstracts were screened by both reviewers independently to assess eligibility, with those considered relevant by either investigator advancing to a full-text review. The initial search prioritised first-hand experiences, however, a number of studies included perspectives from healthcare workers that provided valuable insights into patient experiences. The decision was made to include these studies. The investigator pair fully screened articles to identify studies that fulfilled the following criteria:

- The study focused on the experiences of women and/ or healthcare workers of Indigenous identity across the world.

- Findings contained personal illustrations or firstperson accounts of HPV knowledge and cervical cancer screening.

- The study was qualitative or mixed methods (with clear qualitative examples).

- Where cancer was the phenomenon of interest, studies only focused on cancers associated with HPV infection (mostly cervical cancer, but did not exclude on basis of oropharyngeal cancer).

- The study was available in English.

- The study was available in hardcopy or in downloadable form.

- The study was published prior to 30 June 2020.

Exclusion criteria:

- Based only on HPV vaccination.

- Quantitative only studies.

- Studies that included narratives from men only.

While efforts were made to decrease publication bias, the reviewers recognise that limiting the search to the English language could result in loss of data in other native languages. Additionally, the inclusion of all grey literature could have provided additional findings for the study and decreased possible impacts of publication bias.

\section{Critical appraisal}

There are various validated tools for appraisal of studies; this review employed the JBI (Joanna Briggs Institute) System for the Unified Management, Assessment and Review of Information (SUMARI) critical appraisal tool ${ }^{38}$ (online supplemental file 2). This tool includes questions regarding sample sizes, locations, methods used, techniques used and themes derived. 


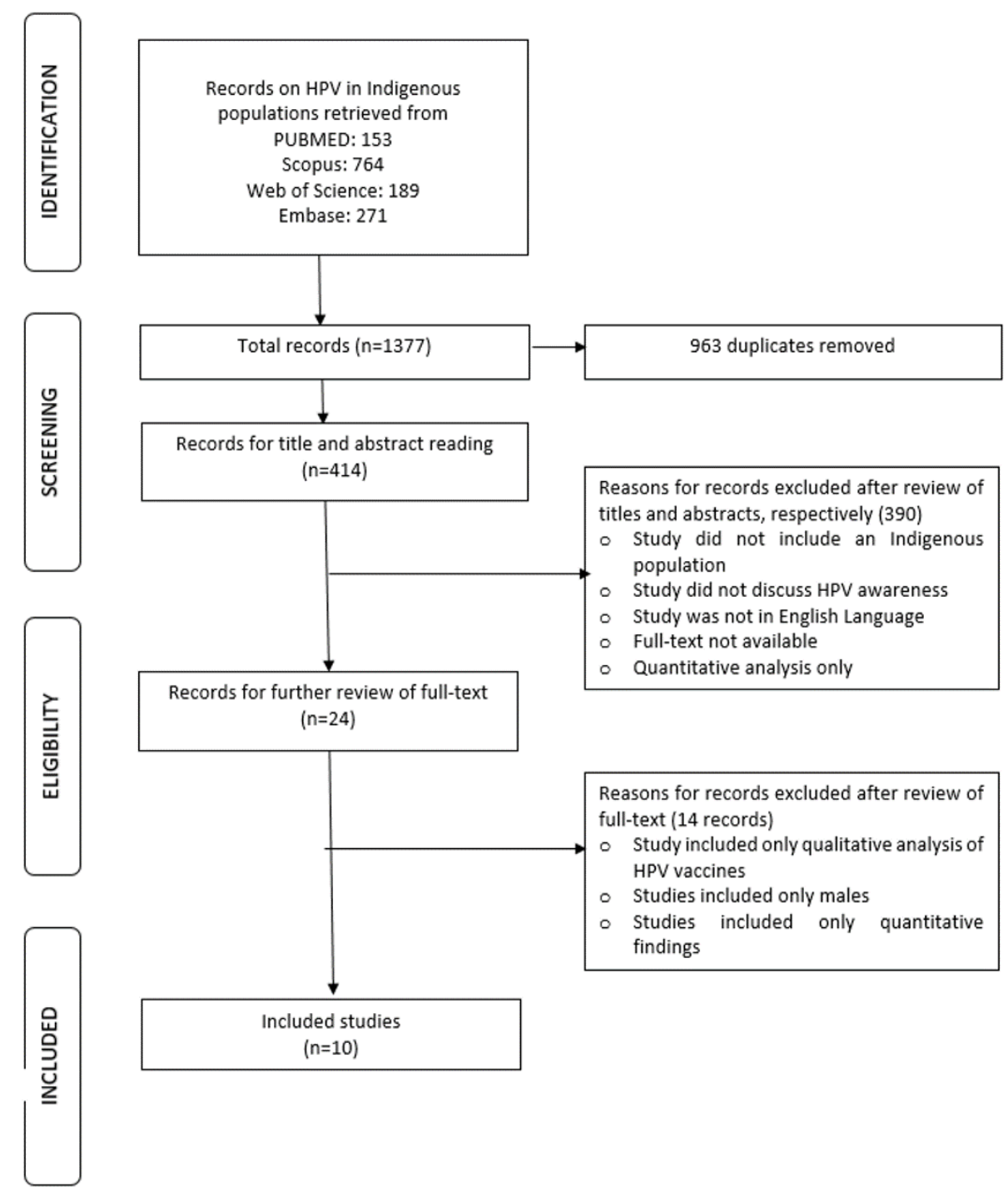

Figure 1 Preferred Reporting Items for Systematic Reviews and Meta-Analyses flowchart for included studies. HPV, human papillomavirus.

\section{Data extraction and synthesis}

Data were extracted in two phases. For the first phase, the reviewers used concepts of thematic analysis and comprehensively identified findings from each of the included studies. These findings were extracted via a piloted extraction form and then uploaded to JBI SUMARI. The second phase used the JBI data extraction tool for all studies. Each reviewer independently scored the findings within JBI SUMARI as 'Credible (C)', 'Not Supported (NS)' and 'Unequivocal (U)'; the score for each finding was based on inter-reviewer agreement. The synthesis of findings was done manually by reviewers, which included writing all findings on a white board and identifying common phrases, themes and concepts. Common themes were grouped, with connections between other themes explored in the context of the lived experience of HPV prevention for an Indigenous woman. These categories were then transferred from the white board to the
JBI SUMARI tool and each individual finding was placed within the appropriate category.

\section{Social ecological model}

On reviewing the categories and creating synthesised themes, it was apparent that findings were present at varying societal levels that are comprehensively identified in the social ecological model. The overarching themes were therefore generated to fit the social ecological model including: (1) intrapersonal factors; (2) interpersonal factors; (3) institutional and organisational factors; (4) sociocultural and community factors; (5) public policy. ${ }^{34}$ This was additional to the solutions provided by the community which included two main themes: selfsampling and community interventions.

\section{RESULTS}

The literature search returned 1377 records, of which 963 were duplicates and consequently excluded. After being 


\begin{tabular}{|c|c|c|c|}
\hline Study & $\begin{array}{l}\text { Questions in } \\
\text { agreement (n) }\end{array}$ & $\begin{array}{l}\text { Questions in } \\
\text { disagreement (n) }\end{array}$ & Score \\
\hline Adcock et al ${ }^{41}$ & 10 & 0 & 10 \\
\hline Allen-Leigh et $a l^{40}$ & 9 & 1 & 9 \\
\hline Butler et $a l^{45}$ & 10 & 0 & 10 \\
\hline Cerigo et a ${ }^{42}$ & 10 & 0 & 10 \\
\hline Henderson et al $1^{19}$ & 10 & 0 & 10 \\
\hline Maar et $a l^{24}$ & 10 & 0 & 10 \\
\hline O'Brien et $a l^{21}$ & 10 & 0 & 10 \\
\hline Tratt et al ${ }^{43}$ & 9 & 1 & 9 \\
\hline Wakewich et al ${ }^{18}$ & 9 & 1 & 9 \\
\hline Zehbe et $a l^{44}$ & 9 & 1 & 9 \\
\hline Mean & & & 9.60 \\
\hline
\end{tabular}

screened against the prespecified inclusion and exclusion criteria, 24 studies were shortlisted. Of the 24 potentially eligible studies reviewed in full, 10 fully satisfied the inclusion criteria (figure 1). The average inter-reviewer score was 9.60, indicating a very high level of agreement between reviewers (table 2). Although some studies $(n=4)$ did not perform well according to the criteria set by the Qualitative Assessment and Review Instrument of method (online supplemental file 3) of quality appraisal, ${ }^{38}$ the reviewers felt that studies should not be excluded on the basis of being 'less rigorous' according to one set of criteria. On the contrary, such studies were included precisely because of the richness of textual narrative provided. Other studies had minor methodological issues pertaining primarily to whether the researchers had adopted a reflexive stance by examining their own role in formulating and conducting the research. ${ }^{39}$

After the literature search and article appraisal, 10 studies were deemed eligible for inclusion in this review. Studies were conducted in four countries: with Māori communities in New Zealand, Aboriginal and Torres Strait Islander population in Australia, Inuit and First Nations communities in Canada, as well as Mam and Huichol communities in Mexico (table 3).

Reviewers identified 118 findings (online supplemental file 4) from the included ten studies, a chart with each finding, associated quotes and score was generated (table 4). This collaborative process resulted in 36 distinct categories, which provided an appropriate template to meta-aggregate the findings. Five main themes were synthesised by the end of this process, with reviewers in complete agreement. After completion of this process, the JBI SUMARI tool generated a meta-aggregation flowchart of all findings, categories and themes.

\section{Intrapersonal factors}

A theme strongly reflected in all included studies was intrapersonal factors. Findings revealed marginal awareness of HPV and cervical cancer, including a lack of knowledge regarding HPV symptoms and disease progression. The lack of awareness of disease progression was highlighted in more than one paper. ${ }^{180-42}$ A deficiency of empathetic services was identified as a potential barrier to seeking timely health support. ${ }^{41}$ Feelings of embarrassment and shyness were the most commonly stated experiences when visiting a doctor for screening. One study suggested that younger women feel shy, especially individuals with a history of sexual abuse, ${ }^{43}$ while another suggested that older women are more hesitant to pursue screening options due to feeling shy. ${ }^{42}$ Māori women have referred to this feeling as whakamā and that its tapu (a taboo) to let go of your body autonomy. ${ }^{41}$ Feelings of vulnerability were common, and experiences of cervical screening were described as vulnerable ${ }^{18}$ :

I remember feeling so vulnerable, just so extremely vulnerable and, and I remember at one point he [the male physician] was talking on his phone while I was up in the stirrups and I thought uh, you know, I wonder how many other patients feel like this ... There's got to be a better, kinder, gentler, more humane way to do it.

Associated with feelings of shyness were previous negative and painful healthcare experiences, which may serve to demotivate women from regular screenings. Specifically, concerns were expressed around sterilisation, empathetic procedures and rushed appointments. ${ }^{40}{ }^{44}$ Another common intrapersonal factor was fear of prognosis; for example, some participants identified this as a barrier because they feared a cancer diagnosis. ${ }^{18} 1944$ However, other participants found fear to be a motivator, and the desire to avoid suffering or death from this disease ensured prioritisation of prevention. ${ }^{19}$ The financial burden associated with the Pap test and other costs including transport or childcare were substantial barriers among low-income families. ${ }^{41}{ }^{44}$ Some studies suggested that healthcare as a whole was not identified as a high priority for many individuals as stated by healthcare workers ${ }^{41}$ :

One in seven had not screened in ten years or more and one in six were unsure how long it had been since their last cervical screen.

Alternatively, one study suggested a deep interest and inclination towards health, where family and personal wellness were identified as motivators ${ }^{45}$ :

It's about listening to my body. It's about trying to keep it healthy for my children. I want to live as long as I can to bring them up to see them. Not only that, I want to feel good too. And I have had friends who have been diagnosed and that motivates me also to do it. But all in all I do it for myself and my family.

\section{Interpersonal processes}

Four of the included studies described factors at the interpersonal level. ${ }^{18} 192145$ Family relations were discussed as a way to facilitate a generational shift from an environment 
Table 3 Characteristics of included studies

\begin{tabular}{|c|c|c|c|c|c|}
\hline Study & $\begin{array}{l}\text { Methods for data } \\
\text { collection and } \\
\text { analysis }\end{array}$ & Country & $\begin{array}{l}\text { Phenomena of } \\
\text { interest }\end{array}$ & $\begin{array}{l}\text { Setting/context/ } \\
\text { culture }\end{array}$ & $\begin{array}{l}\text { Participant } \\
\text { characteristics and } \\
\text { sample size }\end{array}$ \\
\hline Cerigo et $a l^{42}$ & $\begin{array}{l}\text { Mixed methods } \\
\text { and focused group } \\
\text { interviews. Thematic } \\
\text { content analysis using } \\
\text { NVivo software }\end{array}$ & Canada & $\begin{array}{l}\text { Attitudes and } \\
\text { experiences about } \\
\text { cervical cancer Pap } \\
\text { smear and HPV } \\
\text { vaccine }\end{array}$ & $\begin{array}{l}\text { Inuit women in } \\
\text { Nunavik, Quebec }\end{array}$ & $\begin{array}{l}\text { Participant } \\
\text { characteristics: } \\
\text { women, 31-55years. } \\
\text { Sample size: } 6\end{array}$ \\
\hline Tratt et al ${ }^{43}$ & $\begin{array}{l}\text { Fuzzy cognitive } \\
\text { mapping (visual } \\
\text { mapping) mapped and } \\
\text { weighted participant } \\
\text { knowledge to illustrate } \\
\text { the impact of one on } \\
\text { the other }\end{array}$ & Canada & $\begin{array}{l}\text { Explore the possible } \\
\text { implementation of } \\
\text { HPV self sampling }\end{array}$ & $\begin{array}{l}\text { Inuit women in } \\
\text { Nunavik Quebec }\end{array}$ & $\begin{array}{l}\text { Participant } \\
\text { characteristics: all } \\
\text { women over the age } \\
\text { of } 25 \text { years. Sample } \\
\text { size: } 27\end{array}$ \\
\hline Maar et $a l^{24}$ & $\begin{array}{l}\text { Participatory action } \\
\text { research, mixed } \\
\text { methods approach, } \\
\text { semi-structured } \\
\text { interviews. Analysis: } \\
\text { thematic analysis }\end{array}$ & Canada & $\begin{array}{l}\text { Understand the } \\
\text { effective ways } \\
\text { to reach First } \\
\text { Nations women } \\
\text { with screening } \\
\text { information, potential } \\
\text { or promising } \\
\text { strategies to help } \\
\text { motivate women to } \\
\text { participate in cervical } \\
\text { cancer screening and } \\
\text { address the special } \\
\text { issues for First } \\
\text { Nations women with } \\
\text { respect to cervical } \\
\text { cancer screening }\end{array}$ & $\begin{array}{l}\text { First Nations people } \\
\text { in Northwest Ontario } \\
\text { (Lake Superior or } \\
\text { around Lake Nipigon) }\end{array}$ & $\begin{array}{l}\text { Participant } \\
\text { characteristics: First } \\
\text { Nations people in } \\
\text { Northwest Ontario } \\
\text { (Lake Superior or } \\
\text { around Lake Nipigon). } \\
\text { Sample size: } 70-840 \\
\text { members }\end{array}$ \\
\hline
\end{tabular}


Table 3 Continued

\begin{tabular}{|c|c|c|c|c|c|}
\hline Study & $\begin{array}{l}\text { Methods for data } \\
\text { collection and } \\
\text { analysis }\end{array}$ & Country & $\begin{array}{l}\text { Phenomena of } \\
\text { interest }\end{array}$ & $\begin{array}{l}\text { Setting/context/ } \\
\text { culture }\end{array}$ & $\begin{array}{l}\text { Participant } \\
\text { characteristics and } \\
\text { sample size }\end{array}$ \\
\hline $\begin{array}{l}\text { Allen-Leigh et } \\
\left.\mathrm{a}\right|^{40}\end{array}$ & $\begin{array}{l}9 \text { focus groups } \\
\text { (5-11 per group), } \\
29 \text { interviews, } \\
\text { audio recordings, } \\
\text { transcriptions and field } \\
\text { notes taken. Analysis: } \\
\text { two stage coding } \\
\text { process (first level- } \\
\text { descriptive coding; } \\
\text { second stage-pattern } \\
\text { codes) }\end{array}$ & $\begin{array}{l}\text { Mexico (South } \\
\text { America) }\end{array}$ & $\begin{array}{l}\text { Study the barriers to } \\
\text { use of self-sampled } \\
\text { HPV testing and } \\
\text { cytology among low- } \\
\text { income Indigenous } \\
\text { women residing in } \\
\text { rural areas of Mexico }\end{array}$ & $\begin{array}{l}\text { Mam women in } \\
\text { Chiapas, Nahuatl } \\
\text { women in Puebla and } \\
\text { Huichol women in } \\
\text { Jalisco }\end{array}$ & $\begin{array}{l}\text { Participant } \\
\text { characteristics: } 20 \\
\text { years and above, } 3 \\
\text { ethnic groups (Mam } \\
\text { women in Chiapas, } \\
\text { Nahuatl women in } \\
\text { Puebla and Huichol } \\
\text { Women in Jalisco). } \\
\text { Sample size: }\end{array}$ \\
\hline Wakewich et al ${ }^{18}$ & $\begin{array}{l}\text { Participatory action } \\
\text { research framework, } \\
\text { purpose sampling, } \\
\text { traditional 'talking' } \\
\text { circles, interviews. } \\
\text { Analysis: open coding, } \\
\text { NVivo software }\end{array}$ & Canada & $\begin{array}{l}\text { Develop culturally } \\
\text { sensitive approaches } \\
\text { to cervical cancer } \\
\text { screening and to } \\
\text { explore the feasibility } \\
\text { of self-sampling for } \\
\text { HPV as an alternative } \\
\text { screening modality to } \\
\text { Pap cytology }\end{array}$ & $\begin{array}{l}\text { First Nations women } \\
\text { in Northwestern } \\
\text { Ontario }\end{array}$ & $\begin{array}{l}\text { Participant } \\
\text { characteristics: } \\
\text { healthcare workers } \\
\text { and Elders. Sample } \\
\text { size: } 16 \text { interviews of } \\
\text { healthcare workers } \\
\text { and } 8 \text { community } \\
\text { focus groups (total } 69 \\
\text { women) }\end{array}$ \\
\hline Zehbe et $a l^{44}$ & $\begin{array}{l}\text { Data collection: field } \\
\text { trips, teleconferences, } \\
\text { in depth interviews, } 8 \\
\text { focus groups, semi- } \\
\text { structured grounded } \\
\text { theory approach. } \\
\text { Analysis: Nvivo } 9 \text { (QSR } \\
\text { International) }\end{array}$ & Canada & $\begin{array}{l}\text { Experiences with } \\
\text { cancer in their } \\
\text { community, followed } \\
\text { by community } \\
\text { concerns about } \\
\text { cancer, knowledge } \\
\text { and awareness of } \\
\text { cervical cancer }\end{array}$ & $\begin{array}{l}\text { First Nations Women, } \\
\text { Northwest Ontario }\end{array}$ & $\begin{array}{l}\text { Participant } \\
\text { characteristics: } \\
\text { healthcare workers- } \\
20 \text { s to } 60 \text { s age } \\
\text { groups, } 15 \text { HCPs } \\
\text { were women and one } \\
\text { was man. Community } \\
\text { participants - up } \\
\text { to } 70 \text { years age, } \\
\text { women from First } \\
\text { Nations identity of } \\
\text { these, } 10 \text { women } \\
\text { self-identified as First } \\
\text { Nations. Sample } \\
\text { size: } 16 \text { (interviews), } \\
8 \text { focus groups=total } \\
69 \text { women }\end{array}$ \\
\hline Butler et $\left.a\right|^{45}$ & $\begin{array}{l}\text { Convenience } \\
\text { sampling yarning } \\
\text { (followed a question } \\
\text { guide), interpreting, } \\
\text { listening, sharing, } \\
\text { health questionnaire, } \\
\text { audio recordings, } \\
\text { transcriptions } \\
\text { (verbatim) and field } \\
\text { notes. Thematic } \\
\text { analysis (NVivo) }\end{array}$ & Australia & $\begin{array}{l}\text { Barriers and enablers } \\
\text { to cervical cancer } \\
\text { screening }\end{array}$ & $\begin{array}{l}\text { Aboriginal Community } \\
\text { Controlled Health } \\
\text { Services or } \\
\text { Government-run } \\
\text { clinics that serve a } \\
\text { large proportion of } \\
\text { Indigenous clients- } \\
\text { Queensland, New } \\
\text { South Wales, Northern } \\
\text { Territory }\end{array}$ & $\begin{array}{l}50 \text { women (44 } \\
\text { Aboriginal, } 6 \text { Torres } \\
\text { Strait Islander), ages } \\
\text { 25-60, 6-14 women } \\
\text { from five different } \\
\text { Public Healthcare } \\
\text { Centres }\end{array}$ \\
\hline
\end{tabular}

HPV, human papillomavirus.

of sexual taboo to one of love and support. ${ }^{18} 192145$ Rolemodelling by older family members, specifically mothers, was associated with preventive healthcare practices. ${ }^{21}$ One mother explained the importance of talking openly about sex with her children ${ }^{18}$ :
Like my mother, you know, was the kind of woman that ... when I first got my period, I didn't know what it was because that was something you don't talk about, your body like that. It's you know that's your personal, private, so when it happened, I had 
Table 4 Illustrations from all the included studies arranged according to all the synthesised categories under each level of the socio-ecological model

\begin{tabular}{ll}
\hline $\begin{array}{l}\text { Social ecological } \\
\text { model level }\end{array}$ & $\begin{array}{l}\text { Synthesised } \\
\text { finding }\end{array}$ \\
\hline
\end{tabular}

Public policy Trauma

\section{Illustration}

'They have been sexually abused, too, and I know like, in the past residential schools, that kind of thing, those people are just not comfortable because of their experiences in the past .... I will be here for a long time and whenever you need to see me, to come see me, so that even just that little thing and then when they do come I do see them, hopefully that trust builds up and I think that's a big piece with the First Nations'. (p374) ${ }^{18}$

'I think one of the biggest issues um, [short pause] the barriers that prevents people from going to and maybe it's cause it's taboo is because they've been sexually abused'. (p374) ${ }^{18}$

'I guess they were told about some kind of vaccine or something, like years ago, and it was something just, to try to get rid of the Native people'. (p374) ${ }^{18}$

'[Residential schools] "Opened a whole can of worms; when all the illness and substance abuse went on a skyrocket"'. (p96) ${ }^{19}$

'Speaking of a sister in the end-stage of cervical cancer, one middle-aged participant attributed the illness to chronic sexual abuse: "There were a couple times she had STIs [sexually transmitted infections] and didn't really know, may have been HPV or may have been another"'. $(p 96)^{19}$

'In both sharing circles, participants argued that residential school litigation broke students' capacity for intimacy throughout their lives, playing out in self-destructive coping strategies (eg, substance dependence, early sexualization) and increased risk of victimization'. (p96) ${ }^{19}$

'It must be the pesticides that are being sprayed on our cultivated land ... You can see our area and there is a layer of dust in spring and harvest'. (p96) ${ }^{19}$

'Our people are starving for affection, support, respect and love'. (p96) ${ }^{19}$

'The nuns make sure to remind you no matter what you do, you're going to hell'. (p96) ${ }^{19}$

'We were taught to be quiet about our private parts ... a lot of sexual abuse went on, and spiritual, physical, you name it'. (p96) ${ }^{19}$

'One speaker brought these lingering effects of residential schools together by describing a shift in her society from monogamous relationships to relaxed sexual boundaries, noting that with her own daughters she "didn't lay down the law like our parents did"'. (p96) ${ }^{19}$

" "She got an STI because she was taken advantage of" (SC2) by someone other than her partner. The mother connected her daughter's exposure to loss of identity and heavy drinking at parties in her community. Lowered inhibitions brought on by alcohol, and illicit drug use were seen by several other speakers to have become normalized among younger generations, who "see the suffering of their parents and grandparents, and they are running to the substance abuse"'. (p96) ${ }^{19}$

'In both circles, speakers expressed compassion for younger generations today: "It was a lot easier in my time because we would go to ceremonies ... but today, our grandchildren are exposed to drugs, alcohol, everything"'. (p96) $)^{19}$

'He observed that such statistics reflect disrupted connections between partners, between Elders and youth, as well as with nature and spirituality: "We are not islands, we need to be connected to people and that is what is missing"'. (p96) ${ }^{19}$

'Therefore, the burden of HPV in FN people is rooted, at least in part, in efforts by people across the lifespan to cope with the violent disruption of family and community connectedness, as well as connection to land and spirituality. This burden is manifested not only in risk-taking behaviour, but also in avoidance of wider health systems: "I think First Nations don't get checked when they are supposed to, to be honest. They just wait until it is too late to help them"'. (p97) ${ }^{19}$

'Coming from a communal society, another participant observed that today many struggle "to fit into an individualistic society, and we don't fit"'. (p98) ${ }^{19}$

'[When discussing child welfare] "A lot of those kids when they come back to the reserve they are very angry, there are a lot of things that happened [to them] that we don't know about"'. $(p 97)^{19}$

'One health director who was herself FN had not approved the HPV vaccine for her own daughter, believing at the time that vaccines are perhaps "not natural, that they are more chemicals given by the government to hurt us"'. (p98) 
Table 4 Continued

\begin{tabular}{lll}
\hline $\begin{array}{l}\text { Social ecological } \\
\text { model level }\end{array}$ & $\begin{array}{l}\text { Synthesised } \\
\text { finding }\end{array} \quad$ Illustration \\
\hline
\end{tabular}

\begin{tabular}{ll}
\hline & \\
Sociocultural/ & Gender \\
community & imbalances
\end{tabular}

'If I'm drinking and drugging, then I'm going to feel guilty about taking my children to the clinic to help them live a healthier life'. (p98) ${ }^{19}$

'The first time I went to check myself, with the Papanicolaou tests, I had problems. I got beat-up. My husband hit me because he said I had gone to do things with the [male] doctor. When it wasn't even a doctor who examined me, the [female] nurse examined me! She took the sample, but at home my husband didn't believe that'. $(\mathrm{p} 4)^{40}$

'I decided it [to perform the HPV test] myself, alone. I don't ask anyone's permission....,
How am I going to ask him if he [her husband] wants it or not? It's not for him, it's for me'.
(p4)
"Because it's a relationship thing' that implied that someone had 'cheated" (p7). ${ }^{44}$

'... I know only women get cervical cancer but... they've helping it along in the same sense
where they've passing it back and forth' (p7). ${ }^{44}$

STI stigma 'Focus group participants were concerned that any publication of information about HPV rates on reserve could have negative effects, contributing to the stereotype that 'all native people have HPV' (FG6). As one HCP summarized: 'A lot more education has to be done about HPV and cervical cancer together' to alleviate these concerns'. (p7 $)^{44}$

'Definitely there's always going to be a stigma about any kind of thing that's an STD [STI], because people think it's dirty or whatever. Like l've had people come in, like, even the girl just saw with genital warts and she just couldn't believe it and couldn't like fathom who she would have got it from because everyone she's been with has only been with her. Right?'. $(\mathrm{p} 373)^{18}$

'Actually in the last 6 months that l've been there, l've had uh, a minimum of 5 people who have come to me who um, have been concerned about contracting STIs and did not want me writing it into their chart for fear that it would leak into the community ... they're afraid of the stigma surrounding that so and a lot of times too I wasn't able to do any [cervical] screening'. (p373) ${ }^{18}$

\begin{tabular}{|c|c|c|}
\hline & & $\begin{array}{l}\text { 'Health centers on reserves, don't want to spread it out too much how many people } \\
\text { have HPV. I know how the stereotype works if we pass on the information in non-native } \\
\text { communities they will say all native people have HPV'. (p373) }\end{array}$ \\
\hline & Isolating effects & $\begin{array}{l}\text { 'It took time for one family to realize that it was "not just happening to them, it's the whole } \\
\text { community"'. (p96) }\end{array}$ \\
\hline & $\begin{array}{l}\text { Community } \\
\text { support }\end{array}$ & $\begin{array}{l}\text { 'Yeah, just yarning with all the women, you know, getting together, having a cuppa. I think } \\
\text { someone just bringing it up, approaching it in a way where it's just a thing where you're } \\
\text { sitting there having a yarn about-and not feeling shame'. (p9) }\end{array}$ \\
\hline \multirow[t]{4}{*}{$\begin{array}{l}\text { Institutional/ } \\
\text { organisational }\end{array}$} & $\begin{array}{l}\text { Healthcare } \\
\text { worker cultural } \\
\text { awareness }\end{array}$ & $\begin{array}{l}\text { 'Cultural awareness of healthcare workers was a major facilitator, reflected in positive } \\
\text { patient experiences and more use of adequate communication means'. (p3) }{ }^{43}\end{array}$ \\
\hline & & $\begin{array}{l}\text { 'An additional path through which more cultural awareness could have positive impacts on } \\
\text { the use of health services was mediated by increased confidence in patients' capabilities; } \\
\text { thus, allowing a more active role of patient in decision-making'. }(\mathrm{p} 4)^{43}\end{array}$ \\
\hline & & $\begin{array}{l}\text { 'Previous positive experiences of health personnel in their interaction with Inuit was told to } \\
\text { be a factor that highly contributes to increase cultural awareness, countering the negative } \\
\text { effect of a healthcare system based on non-Inuit cultural values'. }(p 4)^{43}\end{array}$ \\
\hline & & $\begin{array}{l}\text { 'Well, word it a way to have to do with childbearing, [which] is a sacred gift that's only given } \\
\text { to women, let's keep our bodies healthy by getting annual check-ups, and you use some } \\
\text { culturally appropriate like pictures, or something'. (p8) } \text { ) }^{24}\end{array}$ \\
\hline
\end{tabular}

'We need to talk to our people in a way they understand, no disrespect to any organization, but people don't look at that material [brochures], it's obvious that the way we deliver that message has to be different'. (p98) ${ }^{19}$

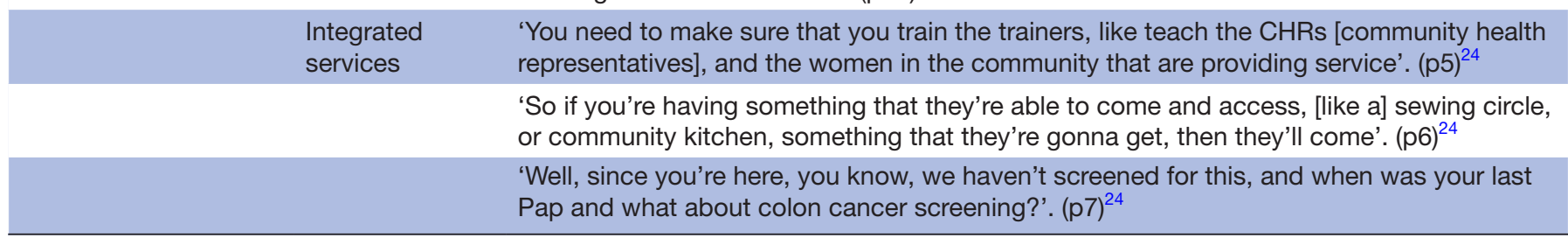


Table 4 Continued

\begin{tabular}{lll}
\hline $\begin{array}{l}\text { Social ecological } \\
\text { model level }\end{array}$ & $\begin{array}{l}\text { Synthesised } \\
\text { finding }\end{array} \quad$ Illustration \\
\hline
\end{tabular}

'If it [other STI testing] can be done on the same swab(as self-sampling), I would say, the value of that would be huge'. $(\mathrm{p} 8)^{24}$

'HCPs felt that education around self-testing might better be done in the context of a well woman healthcare visit, as 'part of a physical, that might get best [results]'. Women would not necessarily understand that they would still need to go to their HCP for other reproductive healthcare: 'They would, they'd probably think, well, I've had that done, so I don't need this done". $(p 7)^{44}$

'Eliminating multiple clinic visits was stressed'. $(p 5)^{41}$

Negative HC 'I still don't know, to this day, whether they found anything or what portion they removed, experience if they even removed anything. I don't know! Nobody explained anything to me because, maybe because I didn't ask. Maybe they thought that I understood everything that was going on, but I didn't'. (p86) ${ }^{21}$

'When you're in (western Canadian city A) and (western Canadian city B) sometimes you just get pushed along as if you're just a file. 'Here you go, this is what's wrong, this is what we're going to do, see you later.' I don't understand where I go from there, how's my health going to be affected by it now'. (p86) $)^{21}$

'... I think it was [hospital name], and they were the roughest they could be in there. They weren't gentle at all, especially having something like that done and they say, "Lay down," and wham, you know, they're in, and that, and it was awful. I said, no, that's it'. (p9) ${ }^{45}$

'Desire for bodily autonomy was often related to negative health experiences (i.e., painful pelvic examinations, inappropriate actions/comments by HCPs)'. (p3) ${ }^{41}$

'We never see a doctor. The health department has to get a hold of us, the ones that are never home. There are a lot of us in the community ... We hear suddenly of these workshops and information centres in the community. We wanted to go but we had other commitments so needed others to go. My niece, she died about 3 years ago because she had cancer. They brought her to Edmonton, they started her on chemo ... left her kids at home'. $(p 97)^{19}$

'One of the girls I used to visit got cervical cancer. She is very angry, she will not talk to me even though I give her support. She was told 3 years ago that she should get the tests and she didn't because she had problems for a long time'. (p97 $)^{19}$

'She [HCP] thinks it's her(that they don't like), 'like, why is no one coming [for screening]' ... 'it's not you, it took me 20 years to get to where I'm at now, and I still get people that don't trust me". (p374) $)^{18}$

'My doctor who I had since my oldest was born, she just up and quit, so when my next appointment, I had this guy looking at me, it's like [pause] right, so it's not like they stick around here'. $(p 375)^{18}$

Language 'Participants reported the major importance of using visual language, ranking higher than using Inuktitut, and they stressed the communication problems behind using French or medical jargon'.(p4) ${ }^{43}$

'I have a sweet little old lady, she's probably close to 80; she won't speak it, she won't speak English, she understands you, she can speak English, but she would rather speak in her own language'. $(p 6)^{25}$

Male healthcare 'I had it done by a male doctor and I was uncomfortable ... because of the way I was worker raised. My [traditional] grandmother always told me that the only man that should know you like that is your husband'. $(p 87)^{21}$

'My first Pap smear was done by a male and I was very nervous and I just didn't want it done. Maybe that's why I didn't have another one [Pap smear] ... because of that [male gender]'. $(\mathrm{p} 87)^{21}$

'Some people don't go [to get Pap smears], maybe they're shy ... all of my friends don't go probably because they are shy or sometimes they don't want to [be] checked by a man, if it is a man that is a nurse'. $(p 3)^{42}$

Positive 'My appointment was scheduled when the offices are closed so I knew he was going to be healthcare giving me some fairly bad news. The office was empty, and the lights were all turned down. experience

\section{It was a real comfortable surroundings. He gave me a lot of information, pamphlets, and} people to phone for support'. (p85) ${ }^{21}$ 
Table 4 Continued

\begin{tabular}{lll}
\hline $\begin{array}{l}\text { Social ecological } \\
\text { model level }\end{array}$ & $\begin{array}{l}\text { Synthesised } \\
\text { finding }\end{array} \quad$ Illustration \\
\hline
\end{tabular}

\begin{tabular}{ll}
\hline $\begin{array}{l}\text { 'Oh, when I have my testing done here they just make you feel so welcome and so warm, } \\
\text { you don't feel so invaded, like a hospital ... Yeah, you feel like a person, you don't seem- } \\
\text { feel like a number'. (p11) }\end{array}$ \\
$\begin{array}{l}\text { 'The women are, you know, fairly open once they're comfortable'. (p6) } \\
\text { 'It's all about trust and relationships, like if you can't build a relationship you're not gonna } \\
\text { get anywhere, you might not even see them again'. (p7) }\end{array}$ \\
$\begin{array}{l}\text { Female } \\
\text { healthcare } \\
\text { worker }\end{array}$ & 'The girls are always looking for female doctors'. (p8) \\
\end{tabular}

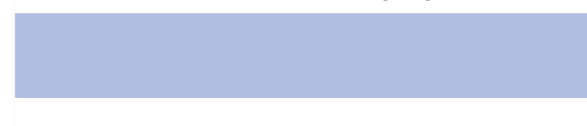

'Feel more comfortable [with a female physician or nurse practitioner] because maybe she's going through the same thing that you're going through'. $(\mathrm{p} 6)^{44}$

'I only got a Pap test once and I got it from a woman ... and she was trying to make me feel comfortable, but it's still really awkward'. (p6) ${ }^{44}$

'... they have got the body parts as me, you know what I mean? And if they've gone
through something similar to this, they'll understand what it's like .... [We have] strong
cultural values on Women's Business too. And it's an invasive procedure, that's how I see
it'. (p10)

Lack of results 'A lot of us say, and we've talked about this before, when we get a Papanicolaou, the results don't arrive, and we don't know what it is that's going on. There we are with the doctor, asking why the results don't arrive. ... Whatever it [the result] is, they should give it to me'. $(\mathrm{p} 4)^{40}$

Privacy

'It's crazy here, how long you have to wait for anything and half the time, you don't even get a call ... you go to your next doctor's appointment for something else and [have to ask] ... by the way, how about my Pap two months ago?'. (p5)

Privacy 'Health centers where staff 'phoning people, telling them, 'we've got your results ... you need to make another appointment' was upsetting'. (p5) ${ }^{44}$

'Especially after, you know, you finish your pap smear and then you're having lunch with
them in the tea room, no thanks'. (p12) ( $^{45}$

'You know what, just sitting in the waiting room, the receptionists are phoning people telling them, we've got your results, you need an, you know, make another appointment, they say the name right out loud, they say what the test is'. $(p 375)^{18}$

'Privacy, a small town, I mean, you can hear through the walls, you know, walls talk because there's, it's all in one building and coming in here and everybody sees the first person coming in here, they come to see me, they come to see welfare, they come to see housing, they're going and everybody knows everything'. (p375) ${ }^{18}$

'Being in reserves, a lot of people know people's business and a lot of people get worried about that when you're trying to keep something personal. I mean the teddy bears talk, the leaves talk, the hydro lines talk'. (p375) ${ }^{18}$

Screening 'I don't know how many times they've cancelled Pap tests and [when I asked] okay well convenience can I get it on Friday? .... [heard back] 'No, we don't do them on Friday". (p5) ${ }^{44}$

'Most of us do not have doctors here ... you have to drive up to [nearby town]'. (p4) ${ }^{44}$ '... when I tell them it was fiveyears, it's a fiveyear one, they're like, "Five years, even better," knowing that they were right for five years and it picks up early, detects things earlier, they were all for it'. $(\mathrm{p} 10)^{45}$

'The availability of screening services outside of work hours and the potential to reduce waiting times in the clinic by having a nurse available to complete screening rather than a doctor were raised as potential solutions'. $(\mathrm{p} 11)^{45}$

'The size of the examination table was a concern for some women, who worried that they may not fit comfortably on the table due to having a larger body size. One woman with a physical disability stated the importance of an accessible, height-adjustable examination table that made screening more comfortable and easy for her'. $(\mathrm{p} 11)^{45}$

'Women were time-poor and struggled to fit screening appointments in amongst commitments to work and family, which took higher priority in women's lives'. (p11) ${ }^{45}$ 
Table 4 Continued

\begin{tabular}{lll}
\hline $\begin{array}{l}\text { Social ecological } \\
\text { model level }\end{array}$ & $\begin{array}{l}\text { Synthesised } \\
\text { finding }\end{array}$ & Illustration \\
\hline Interpersonal factors & Family relations & $\begin{array}{l}\text { 'Well, my mother, you know, always went for her physicals; thus I learned that I was } \\
\text { to go for my physicals ... the families that do have it, you can see that progression of } \\
\text { preventative health care'. (p5) }\end{array}$
\end{tabular}

' ... I didn't get it explained too much about that growing up into a woman off my mum. Whereas I want to do the opposite with my daughter and sort of be one step ahead of her, prepared and ready .... . having that information would be good to have it there for her if she ever does want to know about it'. $(\mathrm{p} 8)^{45}$

'I am learning a lot in these workshops. My mother died of stomach cancer, my sister of stomach cancer. I had 5 girls, and 4 of them went through breast cancer. My oldest daughter, her cancer spread. When they were younger I made sure they all got their needles. But, you know, I have never had a workshop like this. If I get a cold, I can fight it off. When I got those needles, I was told I was able to fight the sicknesses; it won't kill you - that is what I was told. This is really good for my grandchildren; I will take this message home to my family. I have two nurses in my family, they probably know about it, but this is a really good thing I am still learning ... ("speaking in Cree)*I was worried the white people would not take care of us, but they have so far [group laughs]. We need to talk to young ladies about how to take care of themselves'. $(\mathrm{p} 97)^{19}$

'Many of the Elders emphasized that health education within Indigenous contexts is anchored in the love and care for children. For one speaker, this affection involves "hugging your children and telling them 'I love you', you don't say goodbye to anyone”'. (p98) ${ }^{19}$

'There are anti-bullying programs ... and there are cultural programs; some kids are brave and some are afraid of getting immunized, but all the children support each other'. (p98) ${ }^{19}$

'The best teachers are your parents'. $(p 98)^{19}$

'I just taught them that sex isn't, it's not what you call dirty, you know, but there's a certain way you got to go about having, like for sex with a partner, you know, you got to explain that part to them, but to talk openly about sex, it's not what you call a dirty subject, yeah. If you want to know something just feel free to ask'. (p376) ${ }^{18}$

'Like my mother, you know, was the kind of woman that ... when I first got my period, I didn't know what it was because that was something you don't talk about, your body like that. It's you know that's your own personal, private, so when it happened, I had absolutely no knowledge what was going on in my body ... And with my daughter, I didn't want her to have that feeling, so I mean, of course I changed and I explained everything but, and then that's the way things are now, women are more informed than they have been in the past'. $(\mathrm{p} 376)^{18}$

\begin{tabular}{|c|c|c|}
\hline & $\begin{array}{l}\text { Intergenerational } \\
\text { communication }\end{array}$ & $\begin{array}{l}\text { '[My husband] goes and sits with the men and teaches them; for me, I can go out and } \\
\text { explain things to the mothers and the children, and out of respect ... he's getting that } \\
\text { message across [in his sweat lodge ceremonies with men]'. (p98) }{ }^{19}\end{array}$ \\
\hline \multirow[t]{4}{*}{ Intrapersonal factors } & $\begin{array}{l}\text { Lack of } \\
\text { knowledge }\end{array}$ & $\begin{array}{l}\text { 'The vast majority of participating women expressed the need to get screened after } \\
\text { understanding medical facts, including but not limited to the absence of symptoms'. }(p 4)^{43}\end{array}$ \\
\hline & & $\begin{array}{l}\text { 'Between these two sicknesses [HPV and cervical cancer] we're in danger, we should go to } \\
\text { the clinic or a doctor. If we feel pain in the womb, go to a doctor'. (p4) }\end{array}$ \\
\hline & & $\begin{array}{l}\text { 'Moderator: What is cervical cancer, what do you know about cervical cancer? Huichol } \\
\text { woman 1: They say you can die of cancer, if you don't detect it early. Moderator: And } \\
\text { how do you detect it? Huichol woman 1: With the Papanicolaou, doing it periodically. } \\
\text { Moderator: And what's periodically? Huichol woman 1: Every three months. Moderator: } \\
\text { Everyone, how often do you think you need to get a Papanicolaou? Huichol woman 2: } \\
\text { Once a year. Huichol woman 3: Depends on how you feel, once a year or every two years, } \\
\text { I get it every twoyears. Moderator: What do you mean, how you feel? Huichol woman 3: If } \\
\text { you feel burning'. (p4) }\end{array}$ \\
\hline & & $\begin{array}{l}\text { 'Further, we found that some women did not fully understand the purpose of the Pap } \\
\text { smear as a method of cervical cancer screening'. }(p 5)^{42}\end{array}$ \\
\hline
\end{tabular}


Table 4 Continued

\begin{tabular}{ll}
\hline $\begin{array}{l}\text { Social ecological } \\
\text { model level }\end{array}$ & $\begin{array}{l}\text { Synthesised } \\
\text { finding }\end{array}$ \\
\hline
\end{tabular}

Illustration

'A sizable proportion of the women were unable to identify a cervical cancer risk factor and were unsure if detecting cervical cancer early would affect the chance for a cure'. $(p 5)^{42}$

'Although unintended, participants of both focus groups directed the conversation towards an educational focus due to the limited knowledge about HPV, cervical cancer and Pap smears among participants'. (p6) ${ }^{42}$

'A lack of health literacy about HPV and cervical cancer and a lack of appropriate/ empathetic services were also raised as barriers'. $(p 3)^{41}$

'The health centre sent out a notification and a consent form, and they listed the benefits and risks ... and I paid more attention to the risks, and I decided not to allow her to be vaccinated, because as a parent I needed to do what was best for my children'. (p98) ${ }^{19}$

'These young people are lucky to get these different resources ... its scary when you think about it, you didn't think about [the health risk] before, because you didn't know anything about it'. $(p 98)^{19}$

Awareness of 'Explain [what the Pap test is] then they accept the value of early diagnosis: I find that once HPV I explain to them the importance of early detection and [that] it can be treated, they're more agreeable to [a Pap test]'. $(\mathrm{p} 4)^{24}$

'The biggest motivation is education, I think. You know, just teach them, let them know that the service is there, that they need to take it, it's important that they have it'. $(p 4)^{24}$

'We know cervical cancer is $100 \%$ preventable, and I know because I read stats and see statistics that Aboriginal women are the number one on the list for dying from this'. $(p 5)^{24}$

'If you detect it in time, you can take that sickness out so it won't progress any more and with a treatment you are fine'. $(p 4)^{40}$

'There is a vaccine for human papillomavirus. I heard it on the radio, that there are vaccines'. $(p 4)^{40}$

Embarrassment 'For me, I am used to getting my Pap, I'm fine with it. But for the younger girls, [or] the shy ones, [or] those who were sexually abused, they might prefer(the HPV self-sampling method)'. (p4) ${ }^{43}$

'... Whatever the doctor says I just put my hand up, because after having children you don't care really. Just do what you have to do'. $(\mathrm{p} 8)^{45}$

'Among our population, older women reported more feelings of embarrassment than the young women'. $(\mathrm{p} 5)^{42}$

'Embarrassed anyway, no matter who did it'. (p6) ${ }^{44}$

'Desire for bodily autonomy (retaining privacy, control over one's body) as a reason for not attending regular cervical screening-encompasses concepts of whakamā (embarrassment/shyness/reticence), tapu (sacred/taboo/forbidden)'. (p3) ${ }^{41}$

'I remember feeling so vulnerable, just so extremely vulnerable and, and I remember at one point he [the male physician] was talking on his phone while I was up in the stirrups and I thought uh, you know, I wonder how many other patients feel like this .... There's got to be a better, kinder, gentler, more humane way to do it'. (p373) ${ }^{18}$

Fear of 'People are scared. I'm thinking of my sister. She hasn't gone back to get retested. She did prognosis have an abnormal result the first time. I think she's afraid. Some people are afraid that if they do find cancer, it's downhill from there'. (p86) ${ }^{21}$

'My fear is of having [cervical cancer] ... motivates me. I want to have good health. I don't want that kind of a disease'. (p86) ${ }^{21}$

'I would try and keep encouraging her ... to tell her, "If they find it early they can do
something about it." I try and set examples for my clients. I tell people, "Did you know
this lady had this kind of cancer because she never got tested, and they could have done
something about it right away and she would still be here”.'. (p86)
'HPV, like, whoa, I don't have that, like, I don't even want to know if I have that'. (p7)
'Once they corrected the cervical cancer you would end up with cancer somewhere else'.
$(\mathrm{p} 96)^{19}$ 
Table 4 Continued

\begin{tabular}{ll}
\hline $\begin{array}{l}\text { Social ecological } \\
\text { model level }\end{array}$ & $\begin{array}{l}\text { Synthesised } \\
\text { finding }\end{array}$ \\
\hline
\end{tabular}

\section{Illustration}

'Women with children and work commitments also had difficulty arranging childcare and time off work to keep their appointments. As a HCP commented: 'It certainly does pose challenges with regards to babysitting care and the mother being away for an entire day". $(\mathrm{p} 5)^{44}$

'Older women were more likely to mention a previous bad experience and were less likely than younger women to mention cost or other financial barriers. Opinions varied about cost being a barrier (as many clinics offer free cervical screening). Some highlighted hidden costs (transport, parking, childcare)'. (p3) ${ }^{41}$

Healthcare 'One in seven had not screened in ten years or more and one in six were ${ }^{41}$ unsure how long priority it had been since their last cervical screen'. (p2) ${ }^{41}$

'It's about listening to my body. It's about trying to keep it healthy for my children. I want to live as long as I can to bring them up to see them. Not only that, I want to feel good too. And I have had friends who have been diagnosed and that motivates me also to do it. But all in all I do it for myself and my family'. (p6) ${ }^{45}$

'... it's no shame, you have to go and do your tests and all that ... Every women [sic] in Australia have to do it every time, black or white ... I don't get shame, because I want to look after myself and for my health too'. (p8) ${ }^{45}$

'It's just what you do. I brush my teeth. It keeps coming down to that because it really for me is just about general body maintenance, you brush your teeth, you eat your food, I take my tablets ... I do what I have to do'. (p6) ${ }^{45}$

'I'll always remember that lady, and she was so nice too. And she's going, your job now is
mummy, and you've got to be here, have this test every twoyears. And because that was
at my sixweek check-up and I didn't want to have the pap smear, and she's going, you
don't want to leave him. And I'm thinking, oh my God, because I was a single mother, oh
my God, I've got to look after him. So I did; never missed it'. (p9)

Pain '[When they did the Papanicolaou test], maybe they did it wrong. I don't know, but I felt something like a scrape. Then I thought maybe the equipment wasn't disinfected. ... I thought about it a lot before doing it again, because I was afraid'. $(p 4)^{40}$

'The Pap is uncomfortable but it has to be done'. (p5) ${ }^{44}$

'It doesn't get any easier, like the first time and then the next year, it didn't get any easier for me'. (p5) ${ }^{44}$

'I didn’t like the way it felt, that's why I didn't want to go back there'. $(\mathrm{p} 5)^{44}$

'They don't want their Paps [be]cause it hurt'. (p5) ${ }^{44}$

'The test also could be exceptionally painful if providers were 'in a rush' or 'rough' and did the procedure "real quick". $(\mathrm{p} 5)^{44}$

'Some women, when they come to the appointment, they decide they don't want to get a Pap, because it's uncomfortable, they're just afraid'. (p5) ${ }^{44}$

Solutions-self Convenience
sampling

'Informant \#14: I think that's the best idea that has come out of anything, like it's not invasive, you do it in your own home, at your own time ... I.Z.: Whenever you, you know, are ready for it and ... Informant \#14 I think that with education along with it that this is what it is, I think that the success rate will be phenomenal with it because it's in their own home'. (p8). ${ }^{24}$

'It is more comfortable to do it at home ... it's simple'. (p6) ${ }^{44}$

'I think the self-test is beneficial for them all because sometimes people don't have time for appointments to take off work, it [the Pap] is kind of an inconvenience'. (p6) ${ }^{44}$

'Even hearing(about self-testing), people are just, What? Oh, I'd do that, for sure, instead of me going to the doctor'. (p6) $)^{44}$

'Doing a self-test doesn't take very long ... it's something that can be dealt with, done, gone'. (p6) ${ }^{44}$

'I think more people would monitor it that way and test it themselves, like 'well maybe not today, but ... eventually l'm going to try it'. (p6) ${ }^{44}$

'... I think the prevalence(participation in self-testing)rate would go up'. (p5) ${ }^{44}$

'Women wouldn't be so agitated and nervous about having the(self-)test'. (p5) ${ }^{44}$

Continued 
Table 4 Continued

\begin{tabular}{ll}
\hline $\begin{array}{l}\text { Social ecological } \\
\text { model level }\end{array}$ & $\begin{array}{l}\text { Synthesised } \\
\text { finding }\end{array}$ \\
\hline
\end{tabular}

\section{Illustration}

'With participants using terms such as 'easier', 'more comfortable', 'less intrusive' and 'brilliant'(to describe self-testing)'. (p3) ${ }^{41}$

'Participants discussed the value of providing multiple options and flexibility to cater to diverse populations, such as through community outreach services, was suggested for optimum engagement'. (p5) ${ }^{41}$

'It's simple, it's not like you are having forceps in you'. (p376) ${ }^{18}$

Decreased pain 'Well, this one(the self-sampled HPV test)is better, because it is more comfortable to do it'. $(\mathrm{p} 5)^{40}$

Education 'If you hand me a kit, I won't touch it. Because I wouldn't know what to do, what if I did it wrong, or whatever, right, so? And I think a lot of people would be that way'. $(p 7)^{44}$

'You just give a test kit to them at home, the majority of them are just going to throw them out'. (p7) $)^{44}$

'HCPs agreed that with appropriate support and education, HPV self-testing will benefit never/under-screened Māori'. $(p 4)^{41}$

'Most frequently [participants] said they would be happy to do the HPV self-test in a clinic or their own home, and emphasised having good support and education to increase their confidence about properly doing it'. (p5) ${ }^{41}$

$\begin{array}{ll}\text { Privacy } & \text { 'Would feel more comfortable with that(self-test)than a male doctor'. (p6) } \\ & \text { 'Self-testing would also address the 'trust issues' that discouraged women from seeking } \\ \text { care from non-indigenous HCPs'. (p6) } & { }^{44}\end{array}$

'It's a lot less clinical ... stripping down and allowing someone else to do the scraping of the cervix, the whole uncomfortable procedure of going through a Pap opposed to doing it privately in the bathroom on your own is a huge difference'. (p5) ${ }^{44}$

'A lot more private, at home, if you do it by yourself'. (p5) $)^{44}$

'Women would prefer to be discreet, do it themselves and get their own results and not have their results shared with others'. (p5) ${ }^{44}$

Autonomy 'I really strongly believe that ... because I was the one that was doing it(self-sampling), I was the one that was in control ... and this way it gave me the ability to do it myself and I got all the results, they were fine; ... it was also self-empowering, great, I like that'. (p6) ${ }^{44}$

'Option of taking it home might make women "feel more empowered" and contribute to a better relationship with HCPs'. $(p 6)^{44}$

'Think it(self-sampling)would be, I think it would be great, because it provides them with some autonomy and allows them to take control of the situation. That would be really great actually ... I I think it would increase [education opportunities] actually, yup, because it's a lot less clinical right, cause like you say, it's a lot less you know, stripping down and you know, allowing someone else to do the scraping of the cervix, you know, the whole uncomfortable procedure of going through a Pap opposed to doing it privately in the bathroom on your own is a huge difference'. $(p 376)^{18}$

Decreased 'This one [the HPV test] is good because it [cytology or the Papanicolaou test] really does embarrassment embarrass you, not because your husband doesn't want it or doesn't let us, but because it's embarrassing and because of embarrassment we don't do it, and so this(self-sampled HPV test)is good for us'. (p5) ${ }^{40}$

'Because you do it yourself, since always, even if there is trust, you feel a little embarrassed to undress in front of someone else'. $(p 5)^{40}$

'I think it(self-sampling)would definitely be more private ... They wouldn't be so embarrassed ... all kinds of people are easily embarrassed'. (p376) ${ }^{18}$

Solutions-community Informal level community 'Workshops, information sessions: I have lunch and learns. That's a start. There's all different venues bringing that into the community'. $(\mathrm{p} 5)^{24}$ communication

'I would concentrate on a day that's important to the women, like Mother's Day. The mothers would all come and the grandmas would come and the aunts would come. I would have guest speakers come in as well and there would be a dinner, a luncheon, or a feast of some sort. I would bring somebody in who had a little bit of charisma like a Tai Chi instructor who cooks meals'. (p6) ${ }^{24}$ 


\begin{tabular}{|c|c|c|}
\hline $\begin{array}{l}\text { Social ecological } \\
\text { model level }\end{array}$ & $\begin{array}{l}\text { Synthesised } \\
\text { finding }\end{array}$ & Illustration \\
\hline & & $\begin{array}{l}\text { 'I think it's just sort of word of mouth, spreading things around, and just kind of bringing it } \\
\text { up, you know, all the time'. (p7) }\end{array}$ \\
\hline & Humour & $\begin{array}{l}\text { 'We didn't specifically talk about HPV, but we talked about STDs [during the education } \\
\text { session]. Yeah, I think they got it because they still, when they see me on the streets here, } \\
\text { we kind of giggle about it because we used bananas [for the sex education], you know, and } \\
\text { they'll ask me: "Are you bringing bananas next week?" You know, so, it was a fun thing'. } \\
\text { (p6) }{ }^{24}\end{array}$ \\
\hline & Social media & 'You could even [do] something as simple as Facebook. Everybody's on Facebook'. (p5) \\
\hline & Survivor stories & $\begin{array}{l}\text { 'I think if there was someone just sharing stories. If a woman was willing to share her story } \\
\text { that she's had this and got screened early. Girls like to listen to things like that, and the } \\
\text { women like to listen to things like that. I beat this and I did that. Something like that would } \\
\text { motivate them'. (p5) }\end{array}$ \\
\hline & $\begin{array}{l}\text { Positive } \\
\text { inspiration }\end{array}$ & $\begin{array}{l}\text { '.... and being a health worker too because then I can say, "No, I do mine," ... it feels a bit } \\
\text { shame but you can talk to your patient and encourage them to do it because you've done } \\
\text { it and if I hadn't done it, well, I shouldn't be saying those things to the patient'. (p12) }\end{array}$ \\
\hline
\end{tabular}

absolutely no knowledge what was going on in my body ... And with my daughter I didn't want her to have that feeling, so I mean, of course I changed and I explained everything.

Intergenerational communication was also identified as important for educating children and as a critical aspect of cultural traditions ${ }^{19}$

[My husband] goes and sits with the men and teaches them; for me, I can go out and explain things to the mothers and the children and out of respect ... he's getting that message across [in his sweat lodge ceremonies with men].

\section{Institutional/organisational factors}

All of the included studies discussed factors at the institutional/organisational level that impacted cervical screening. Some items such as cultural awareness among healthcare workers, integrated services, female healthcare workers for screening and positive healthcare experiences were discussed as facilitators for screening. However, other institutional aspects such as negative healthcare experiences, language barriers, male healthcare workers for screening, lack of results, privacy concerns and screening availability were identified as barriers to screening. Both participants and healthcare workers suggested integrated services (Pap smears combined with other services) as a way to eliminate multiple clinic visits. $^{21} 4144$ Offering services in local languages, eliminating medical jargon ${ }^{21} 43$ and incorporating holistic healthcare approaches were identified as potential facilitators. Geographically remote communities described difficulties associated with building trusting relationships at healthcare centres, due to a high turnover of healthcare workers. ${ }^{18}$ Discussions of the gender of the healthcare worker performing screening services (such as a Pap) elicited strong responses, with male healthcare workers identified as a barrier ${ }^{19} 42$ and female healthcare workers as a facilitator. ${ }^{21445}$ Especially in smaller communities, lack of privacy was a substantial concern that impacted decisions to access healthcare services, ${ }^{18} 44$ as evident in the following quote ${ }^{18}$ :

Being in reserves, a lot of people know people's business and a lot of people get worried about that when you're trying to keep something personal. I mean the teddy bears talk, the leaves talk, the hydro lines talk.

Lack of communication about results and lack of screening availability ${ }^{4045}$ were highlighted as obstacles to accessing services; many participants expressed a desire to receive results regardless of negative or positive outcomes. Positive healthcare experiences enticed regular utilisation of services, ${ }^{19}{ }^{21}$ while negative healthcare experiences impeded the use of services. ${ }^{18} 1941$ Specifically, participants felt that often procedures were not fully explained, ${ }^{18} 19$ which competed with a desire for body autonomy. The frustration of this experience was felt by many participants, as shown in the following quotation $^{19}$ : 
I still don't know, to this day, whether they found anything or what portion they removed, if they even removed anything. I don't know! Nobody explained anything to me because, maybe because I didn't ask. Maybe they thought that I understood everything that was going on, but I didn't.

\section{Sociocultural/community}

This theme was separated into 5 categories, with key quotes arising from 6 of the 10 included studies. Gender imbalances highlighted male dominance in communities, and the consequential inequalities based on gender. Male tendencies towards promiscuity were considered to be a contributing factor for bringing HPV into the home, which affected screening practices due to the associated stigma of an unfaithful partner. ${ }^{44}$ Religious and cultural beliefs prevented many women from attending cervical screening and/or treatment. Women shared their experiences of violence and a general disregard for their health by their male partners ${ }^{40}$ :

The first time I went to check myself, with the Papanicolaou tests, I had problems. I got beat-up. My husband hit me because he said I had gone to do things with the [male] doctor. When it wasn't even a doctor who examined me, the [female] nurse examined me! She took the sample, but at home my husband didn't believe that.

One healthcare worker indicated an urgent need for education to alleviate the negative concerns and sense of humiliation associated with cervical screening. ${ }^{44}$ Healthcare workers in one study described patient requests to not document diagnoses and feelings of nervousness around potential breaches of confidentiality in the community ${ }^{18}$ :

Actually in the last 6 months that I've been there, I've had uh, a minimum of 5 people who have come to me who um, have been concerned about contracting STIs and did not want me writing it into their chart for fear that it would leak into the community ... they're afraid of the stigma surrounding that so and a lot of times too I wasn't able to do any [cervical] screening

Participants frequently described a fear of disappointing community and family; that sense of shame and humiliation was a prime concern and barrier to regular screening. ${ }^{43}$ Discussing the isolating effects of a cervical cancer diagnosis, one study reflected on how the diagnosis of a single person is the suffering of not one individual but an entire community. ${ }^{18}$

\section{Public policy}

While participants in the included studies tended to focus on discussions of institutional/organisational and intrapersonal factors, two of the Canadian studies ${ }^{18} 19$ highlighted the impact of traumatic experiences on accessing screening services. Specifically, the sexual abuse experienced at government-mandated residential schools in Canada has created an environment of sexual taboo where health concerns are not discussed, and services are not sought. This sentiment is illustrated by the following quotation $^{18}$ :

They have been sexually abused, too, and I know like, in the past residential schools, that kind of thing, those people are just not comfortable because of their experiences in the past.

A lack of community connection and relationships was discussed as a consequence of the sexual abuse experienced in residential schools, and substance-dependence was identified as a coping mechanism. ${ }^{18}$ Intergenerational trauma and child removal were also mentioned as barriers to accessing health services, both of which are a result of government-mandated public policies. ${ }^{46}$

\section{Solutions}

Many participants identified solutions to the aforementioned obstacles which were categorised at each level of the social ecological model. Self-sampling ${ }^{18} 214041$ and

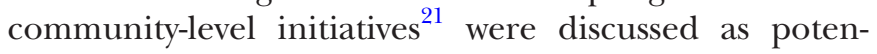
tial ways forward to address some of the concerns and common experiences shared across all included studies. The idea of self-sampling was associated with increased convenience, ${ }^{18214144}$ privacy $^{44}$ and autonomy ${ }^{1844}$ as well as reduced embarrassment ${ }^{18} 40$ and pain. ${ }^{40}$ The need for education prior to self-sampling was stressed as a means to ensure a sound understanding and completion of tests. ${ }^{414}$ The potential increase in perceived bodily autonomy increased the acceptance of self-sampling ${ }^{44}$ :

I really strongly believe that $\ldots$ because I was the one that was doing it [self-sampling], I was the one that was in control ... and this way it gave me the ability to do it myself and I got all the results, they were fine; ... it was also self-empowering, great, I like that.

Maar et al discussed a variety of community-level tactics to increase engagement and a desire to seek out and use healthcare services. ${ }^{24}$ Informal community communication at events as well as by word of mouth was seen as valuable. Integrating HPV screening with femaleoriented celebrations and workshops was discussed as a way to support screening behaviours. Use of school education, survivor stories, social media, incentives and humour were all identified as potential pathways to increasing screening participation. One healthcare worker described how she used humour in an educational workshop ${ }^{24}$ :

We didn't specifically talk about HPV, but we talked about STDs. Yeah I think they got it because they still, when they see me on the streets here, we kind of giggle about it because we used bananas [for the sex education], you know, and they'll ask me: 'Are you bringing bananas next week?' You know, so it was a fun thing. 


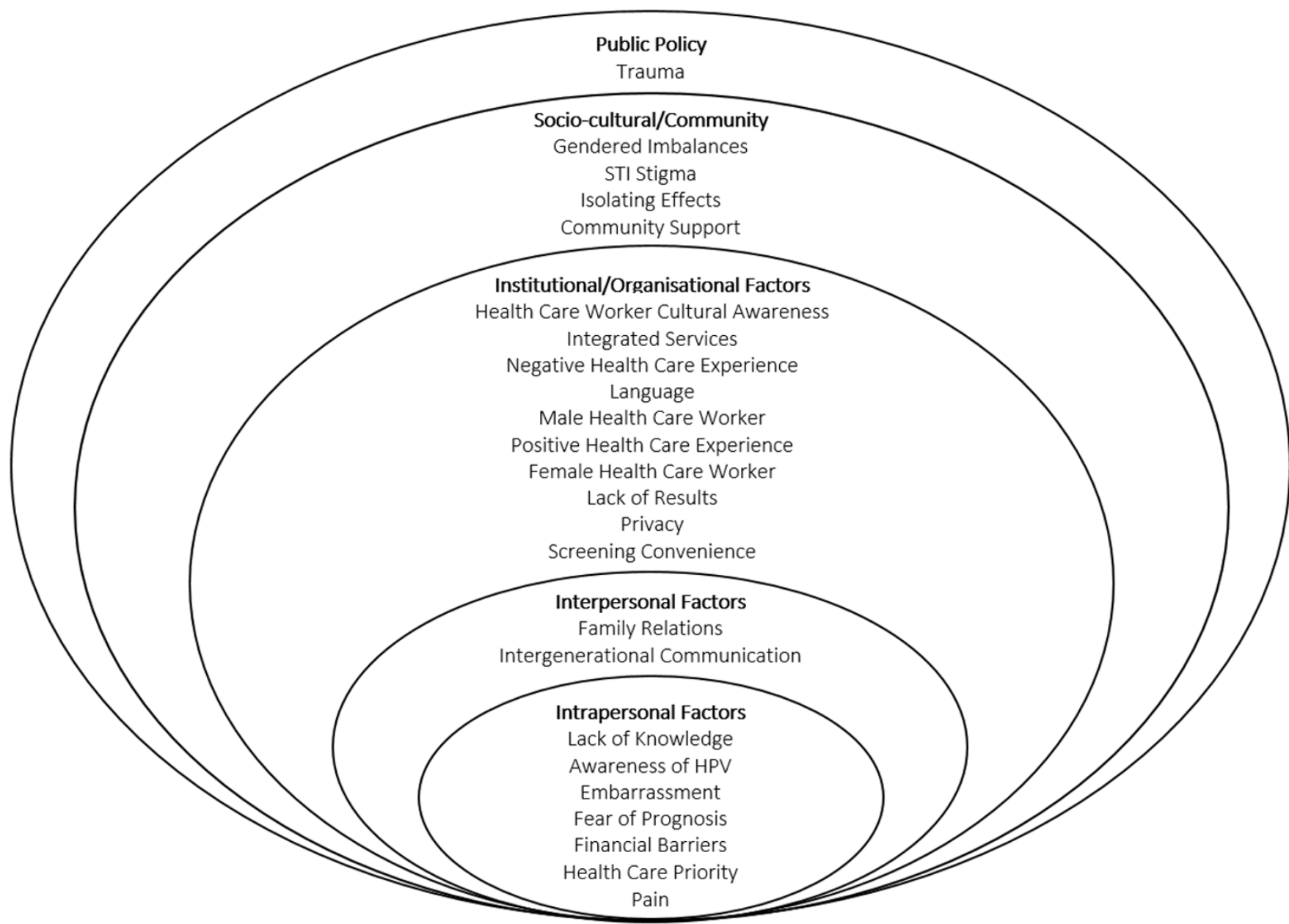

Figure 2 Socio-ecological model. HPV, human papillomavirus; STI, sexually transmitted infection.

\section{Social ecological model}

Two studies explored experiences relevant on all five levels of the social ecological model. All included studies addressed issues on at least two levels of the model (figure 2). Five studies incorporated themes or frameworks that focused exclusively on two ecological levels. All studies discussed factors at the institutional and intrapersonal level, while two studies focused primarily on themes related to public policies. The distribution of themes proposed at each ecological level of the model, according to all included studies is included in table 5 .

Table 5 Social ecological model distribution of studies

\begin{tabular}{|c|c|c|c|c|c|}
\hline Studies & $\begin{array}{l}\text { Public } \\
\text { policy }\end{array}$ & $\begin{array}{l}\text { Sociocultural/ } \\
\text { community factors }\end{array}$ & $\begin{array}{l}\text { Institutional/ } \\
\text { organisational factors }\end{array}$ & $\begin{array}{l}\text { Interpersonal } \\
\text { factors }\end{array}$ & $\begin{array}{l}\text { Intrapersonal } \\
\text { factors }\end{array}$ \\
\hline \multicolumn{6}{|l|}{ Adcock et $a l^{41}$} \\
\hline \multicolumn{6}{|c|}{ Cerigo et $a l^{42}$} \\
\hline \multicolumn{6}{|c|}{ Henderson et al ${ }^{19}$} \\
\hline \multicolumn{6}{|c|}{ Tratt et al ${ }^{43}$} \\
\hline \multicolumn{6}{|c|}{ Wakewich et al ${ }^{18}$} \\
\hline \multicolumn{6}{|c|}{ Zehbe et $a /^{44}$} \\
\hline Butler et al ${ }^{45}$ & & & & & \\
\hline
\end{tabular}

Highlighted boxes show the contribution of a study to a particular ecological level. 


\section{DISCUSSION}

The aim of this systematic review was to collate the experiences of Indigenous women and healthcare workers with regards to HPV, associated cancers and screening methods. A secondary aim was to generate an understanding to inform future HPV prevention strategies. By mapping findings within the social ecological model levels, this review highlights gaps in current HPV practices and identifies areas to be addressed based on firsthand experiences.

The first level of the social ecological model included factors at an intrapersonal level. Lack of knowledge and awareness of HPV infection and its risks persisted in the context of other priorities taking precedence over routine health checks. Two prominent barriers were expressed in all papers: financial burdens and feelings of embarrassment. These factors affect an individual's personal decision to seek screening or preventive healthcare services.

The level of interpersonal factors revolved around two main concepts of family relations and intergenerational communication. The communication within one family unit, from parents to children and even the openness of children with their parents, around discussions involving sexual behaviour and practices was taboo. A greater emphasis on, and openness to, education across the life course could increase the acceptability of screening. A lack of intergenerational communication was identified as a potential predisposing factor to higher risk sexual behaviours.

The third level of the social ecological model, institutional/organisational, had nine synthesised findings that demonstrated how positive and negative healthcare experiences impact current perceptions towards screening and HPV infection. There was an emphasis on lack of empathy by some healthcare workers (doctors, nurses, etc) while screening and dealing with sensitive procedures. A preference of being attended to by female healthcare workers, especially for cervical smears and examination, was observed. Worry due to lack of results after the tests was common, and often was interpreted as bad news which had an impact on participant's daily life and mental health.

The fourth level, sociocultural/community, includes factors that affect HPV-associated cancer prevention and awareness at a community level. This level included discrimination on the basis of gender and highlights male dominance that exists in some communities. This level also examined the stigma and shame of being diagnosed with a sexually transmitted infection and a common fear of being seen at the doctor's office. The experience of isolation faced after diagnosis/treatment is also a common barrier that impedes regular screening.

The results of the systematic review found trauma as the single synthesised finding at the social ecological model level of public policy. Personal quotes revealed the impacts of sexual abuse, physical abuse, drug abuse and traumatic ancestral experiences which continue to have an intergenerational impact across families and communities. Findings revealed a general mistrust towards the health system and healthcare workers. These findings highlight the urgent need to begin building trust between Indigenous communities and local health services in the provision of culturally safe care. Increased trust could help increase the acceptability of current prevention programmes and treatment solutions.

In addition to the themes of the social ecological model, the theme of self-sampling was prominent in most papers. Self-sampling is a solution which may provide more control, independence, privacy and convenience, and in turn increase screening participation. Communityidentified solutions included the use of local survivor stories, which were thought to provide strength and courage to other community members to attend regular cervical cancer screenings and to not fear the diagnosis or to overcome the fear by taking preventative steps. The use of humour and social media were both innovative and socially acceptable solutions for creating awareness and educating community members with contemporary knowledge of HPV infection and its effects.

\section{Strengths and limitations}

To the best of our knowledge, this systematic review is the first to address the qualitative aspects of HPV infection and associated cancers among Indigenous women at a global level. The review adhered to all protocols to ensure transparency and legitimacy. Another strength is the summary of community-provided solutions, in the form of personal narratives, to help decrease transmission of HPV infection and to, in turn, prevent HPV-related cancers. An innovative strength of this study is the inclusion of the social ecological model as a theoretical framework. This model enables conceptualisation of a more holistic approach to HPV prevention for Indigenous women at a global level. In accordance with other studies, our study highlighted the continuing impact of trauma at the public policy level, with our findings providing important evidence of the work required to address the resulting disparities across all health indicators that have resulted from this trauma. ${ }^{46-48}$

Limitations include the decision to not include male participants, as the current statistics show a dramatic increase in the incidence of HPV-associated oropharyngeal carcinoma among men. ${ }^{49}$ Additionally, the majority of articles are from Canada. This highlights the need for more research focusing on Indigenous perspectives and experiences regarding HPV screening and diagnosis in other countries. The community-identified solutions presented are mainly from one study. There is a lack of embedded community feedback in the studies included in this review despite the well-documented importance of community suggestions in improving the acceptability and success of Indigenous health programmes. Future policies and initiatives should prioritise Indigenous voices through incorporation of community suggestions. 


\section{CONCLUSION}

Qualitative systematic reviews are increasing in the literature. They have particular utility in informing policy decisions, as the success of any new policy or intervention depends on its acceptance of, and sustainability in, a given population. While quantitative studies provide clarity with respect to disease spread or burden of a health condition, qualitative studies play a significant role in the management and generation of possible solutions to that health condition/disease. The social ecological model has a structured, multi-level approach with sociological, behavioural and individual aspects. Future research needs to expand the geographical scope of the current work, beyond Canada, and integrate communityidentified solutions. Policies around HPV screening and diagnosis for Indigenous communities, globally, need to prioritise a holistic approach to healthcare, addressing barriers and facilitators at each level of the social ecological model, and prioritising specific community needs.

Contributors SS, BP and JH conceived the presented idea. SS, BP, XJ, LMJ developed the theory and performed the data collection. MS, KC, GG verified the analytical methods. JH encouraged SS and BP to explore the cultural limitations and beliefs leading to inaccessibility of cervical cancer screening. MS, KC, GG and LMJ supervised the work. SS and BP primarily wrote the manuscript under the supervision of GG, MS, KC, LMJ and XJ. All the authors discussed the results and contributed to the final manuscript.

Funding The authors have not declared a specific grant for this research from any funding agency in the public, commercial or not-for-profit sectors.

Competing interests None declared.

Patient consent for publication Not required.

Provenance and peer review Not commissioned; externally peer reviewed.

Data availability statement All data relevant to the study are included in the article or uploaded as supplementary information. All data relevant to the study are included in the article or uploaded as supplementary information.

Supplemental material This content has been supplied by the author(s). It has not been vetted by BMJ Publishing Group Limited (BMJ) and may not have been peer-reviewed. Any opinions or recommendations discussed are solely those of the author(s) and are not endorsed by BMJ. BMJ disclaims all liability and responsibility arising from any reliance placed on the content. Where the content includes any translated material, BMJ does not warrant the accuracy and reliability of the translations (including but not limited to local regulations, clinical guidelines, terminology, drug names and drug dosages), and is not responsible for any error and/or omissions arising from translation and adaptation or otherwise.

Open access This is an open access article distributed in accordance with the Creative Commons Attribution Non Commercial (CC BY-NC 4.0) license, which permits others to distribute, remix, adapt, build upon this work non-commercially, and license their derivative works on different terms, provided the original work is properly cited, appropriate credit is given, any changes made indicated, and the use is non-commercial. See: http://creativecommons.org/licenses/by-nc/4.0/.

\section{ORCID iDs}

Sneha Sethi http://orcid.org/0000-0002-3571-5298

Gail Garvey http://orcid.org/0000-0001-5065-5716

Xiangqun Ju http://orcid.org/0000-0003-4759-3918

Lisa M Jamieson http://orcid.org/0000-0001-9839-9280

\section{REFERENCES}

1 Axelsson P, Kukutai T, Kippen R. The field of Indigenous health and the role of colonisation and history. J Popul Res 2016;33:1-7.

2 Paradies Y. Colonisation, racism and Indigenous health. J Popul Res 2016;33:83-96.
3 Richmond CAM, Ross NA. The determinants of first nation and Inuit health: a critical population health approach. Health Place 2009;15:403-11.

4 Valeggia CR, Snodgrass JJ. Health of Indigenous peoples. Annu Rev Anthropol 2015;44:117-35.

5 Gracey M, King M. Indigenous health part 1: determinants and disease patterns. Lancet 2009;374:65-75.

6 Bombay A, Matheson K, Anisman H. The intergenerational effects of Indian residential schools: implications for the concept of historical trauma. Transcult Psychiatry 2014;51:320-38.

7 Rigney LI. Native title, the stolen generation and reconciliation. Interventions 1998;1:125-30.

8 Williams DV. The continuing impact of amalgamation, assimilation and integration policies. J R Soc N Z 2019;49:34-47.

9 Adelson N. The embodiment of inequity: health disparities in Aboriginal Canada. Can J Public Health 2005;96 Suppl 2:S45-61.

10 Sa T, J P, K P. Assimilation and acculturation in native Hawaiian and other Pacific Islander (NHOPI) health and well-being. POJ Nurs Prac Res 2020;4:1-5.10.32648/2577-9516/4/1/1

11 Allan B, Smylie J. First peoples, second class treatment: the role of racism in the health and well-being of Indigenous peoples in Canada. Toronto: Wellesley Institute, 2015.

12 Bourassa C, McKay-McNabb K. Racism, Sexism and Colonialism: The Impact on the Health of Aboriginal Women. In: Canadian woman studies: an introductory reader. Toronto: Inanna Publications, 2006: 540-51.

13 Browne AJ, Smye VL, Varcoe C. The relevance of postcolonial theoretical perspectives to research in Aboriginal health. Can J Nurs Res 2005;37:16-37.

14 Leeuw Sde, Maurice S, Holyk T. With reserves: colonial geographies and first nations health. Annals of the Association of American Geographers 2012;102:904-11.

15 UN. Indigenous peoples at the United nations. Available: https:// www.un.org/development/desa/indigenouspeoples/about-us.html

16 World Health Organization. World health assembly adopts global strategy to accelerate cervical cancer elimination, 2020. Available: https://www.who.int/news/item/19-08-2020-world-healthassembly-adopts-global-strategy-to-accelerate-cervical-cancerelimination

17 Lawton B, Heffernan M, Wurtak G, et al. IPVS policy statement addressing the burden of HPV disease for Indigenous peoples. Papillomavirus Res 2020;9:100191.

18 Wakewich P, Wood B, Davey C, et al. Colonial legacy and the experience of first nations women in cervical cancer screening: a Canadian multi-community study. Crit Public Health 2016;26:368-80.

19 Henderson RI, Shea-Budgell M, Healy C, et al. First nations people's perspectives on barriers and supports for enhancing HPV vaccination: foundations for sustainable, community-driven strategies. Gynecol Oncol 2018;149:93-100.

20 Garland SM, Brotherton JML, Condon JR, et al. Human papillomavirus prevalence among Indigenous and non-Indigenous Australian women prior to a national HPV vaccination program. BMC Med 2011;9:104.

21 O'Brien BA, Mill J, Wilson T. Cervical screening in Canadian first nation Cree women. J Transcult Nurs 2009;20:83-92.

22 Whop LJ, Garvey G, Baade P, et al. The first comprehensive report on Indigenous Australian women's inequalities in cervical screening: a retrospective registry cohort study in Queensland, Australia (20002011). Cancer 2016;122:1560-9.

23 Shannon GD, Franco OH, Powles J, et al. Cervical cancer in Indigenous women: the case of Australia. Maturitas 2011;70:234-45.

24 Maar M, Burchell A, Little J, et al. A qualitative study of provider perspectives of structural barriers to cervical cancer screening among first nations women. Women's Health Issues 2013;23:e319-25.

25 Decker KM, Demers AA, Kliewer EV, et al. Pap test use and cervical cancer incidence in first nations women living in Manitoba. Cancer Prev Res 2015;8:49-55.

26 Craig Rushing S, Stephens D, Shegog R, et al. Healthy native youth: improving access to effective, Culturally-Relevant sexual health curricula. Front Public Health 2018;6:225.

27 Balbinotto G, Jardim A. Epidemiology and economic impact of cervical cancer in the state of Romania (Brazilian Amazonic region); the perspective of the Brazilian unified health system. Int J Gynaec Obs 2012;119:S3.

28 Cervantes J, Lema C, Hurtado L, et al. Prevalence of human papillomavirus infection in rural villages of the Bolivian Amazon. Rev Inst Med Trop Sao Paulo 2003;45:131-5.

29 Demers A, Shearer B, Totten S, et al. P1-S2.69 prevalence of HPV infections in Metis and first nations living in Manitoba, Canada. Sex Transm Infect 2011;87:A152. 
30 Blakely T, Kvizhinadze G, Karvonen T, et al. Cost-Effectiveness and equity impacts of three HPV vaccination programmes for schoolaged girls in New Zealand. Vaccine 2014;32:2645-56.

31 Deluca GD, Basiletti J, Schelover E, et al. Chlamydia trachomatis as a probable cofactor in human papillomavirus infection in Aboriginal women from northeastern Argentina. Braz J Infect Dis 2011;15:567-72.

32 Rhodes JE. A model of youth mentoring. In: DuBois D, Karcher $M$, eds. Handbook of youth mentoring. Thousand Oaks, CA: Sage Publications, 2005: 30-43.

33 Goldenberg SM, Strathdee SA, Gallardo M, et al. "Over here, it's just drugs, women and all the madness": The HIV risk environment of clients of female sex workers in Tijuana, Mexico. Soc Sci Med 2011;72:1185-92.

34 Bronfenbrenner U. Developmental research, public policy, and the ecology of childhood. Child Dev 1974;45:1-5.

35 McLeroy KR, Bibeau D, Steckler A, et al. An ecological perspective on health promotion programs. Health Educ Q 1988;15:351-77.

36 Moher D, Liberati A, Tetzlaff J, et al. Preferred reporting items for systematic reviews and meta-analyses: the PRISMA statement. PLoS Med 2009;6:e1000097.

37 Petticrew M, Roberts $\mathrm{H}$. Systematic reviews in the social sciences. Oxford, UK: Blackwell Publishing, 2006.

38 The Joanna Briggs Institute. Joanna Briggs Institute Reviewers' Manual. 2014 ed. Adelaide: The Joanna Briggs Institute, 2014.

39 Tucker JD, Tso LS, Hall B, et al. Enhancing public health HIV interventions: a qualitative Meta-Synthesis and systematic review of studies to improve linkage to care, adherence, and retention. EBioMedicine 2017;17:163-71.

40 Allen-Leigh B, Uribe-Zúñiga P, León-Maldonado L, et al. Barriers to HPV self-sampling and cytology among low-income Indigenous women in rural areas of a middle-income setting: a qualitative study. BMC Cancer 2017;17:734.

41 Adcock A, Cram F, Lawton B, et al. Acceptability of self-taken vaginal HPV sample for cervical screening among an under-screened Indigenous population. Aust N Z J Obstet Gynaecol 2019;59:301-7.

42 Cerigo H, Macdonald ME, Franco EL, et al. Inuit women's attitudes and experiences towards cervical cancer and prevention strategies in Nunavik, Quebec. Int J Circumpolar Health 2012;71:17996.

43 Tratt E, Sarmiento I, Gamelin R, et al. Fuzzy cognitive mapping with Inuit women: what needs to change to improve cervical cancer screening in Nunavik, Northern Quebec? BMC Health Serv Res 2020;20:529.

44 Zehbe I, Wakewich P, King A-D, et al. Self-Administered versus provider-directed sampling in the Anishinaabek cervical cancer screening study (ACCSS): a qualitative investigation with Canadian first nations women. BMJ Open 2017;7:e017384.

45 Butler TL, Anderson K, Condon JR, et al. Indigenous Australian women's experiences of participation in cervical screening. PLoS One 2020;15:e0234536.

46 Vallesi S, Wood L, Dimer L, et al. "In Their Own Voice"Incorporating Underlying Social Determinants into Aboriginal Health Promotion Programs. Int J Environ Res Public Health 2018;15:1514

47 Reilly RE, Doyle J, Bretherton D, et al. Identifying psychosocial mediators of health amongst Indigenous Australians for the heart health project. Ethn Health 2008;13:351-73.

48 Barnett L, Kendall E. Culturally appropriate methods for enhancing the participation of Aboriginal Australians in health-promoting programs. Health Promot J Austr 2011;22:27-32.

49 Lechner M, Breeze CE, O'Mahony JF, et al. Early detection of HPVassociated oropharyngeal cancer. Lancet 2019;393:2123. 